\title{
Conventional and Emerging Extraction Processes of Flavonoids
}

\author{
Mónica L. Chávez-González ${ }^{1, *(\mathbb{D})}$, Leonardo Sepúlveda ${ }^{1}\left(\mathbb{D}\right.$, Deepak Kumar Verma ${ }^{2}$, \\ Hugo A. Luna-García ${ }^{1}$, Luis V. Rodríguez-Durán ${ }^{3} \mathbb{D}$, Anna Ilina ${ }^{1}$ and Cristobal N. Aguilar $1, * \mathbb{D}$ \\ 1 Bioprocesses and Bioproducts Research Group, Food Research Department, School of Chemistry, \\ Universidad Autónoma de Coahuila, 25280 Saltillo, Mexico; leonardo_sepulveda@uadec.edu.mx (L.S.); \\ hugoluna@uadec.edu.mx (H.A.L.-G.); annailina@uadec.edu.mx (A.I.) \\ 2 Agricultural and Food Engineering Department, Indian Institute of Technology Kharagpur, \\ Kharagpur 721302, India; deepak.verma@agfe.iitkgp.ernet.in \\ 3 Department of Biochemical Engineering, Unidad Académica Multidisciplinaria Mante, Universidad \\ Autónoma de Tamaulipas, 89840 Ciudad Mante, Mexico; luis.duran@docentes.uat.edu.mx \\ * Correspondence: monicachavez@uadec.edu.mx (M.L.C.-G.); cristobal.aguilar@uadec.edu.mx (C.N.A.); \\ Tel.: +52-844-416-1238 (M.L.C.-G.)
}

Received: 14 January 2020; Accepted: 24 February 2020; Published: 7 April 2020

\begin{abstract}
Flavonoids are a group of plant constituents called phenolic compounds and correspond to the nonenergy part of the human diet. Flavonoids are found in vegetables, seeds, fruits, and beverages such as wine and beer. Over 7000 flavonoids have been identified and they have been considered substances with a beneficial action on human health, particularly of multiple positive effects because of their antioxidant and free radical scavenging action. Although several studies indicate that some flavonoids have provident actions, they occur only at high doses, confirming in most investigations the existence of anti-inflammatory effects, antiviral or anti-allergic, and their protective role against cardiovascular disease, cancer, and various pathologies. Flavonoids are generally removed by chemical methods using solvents and traditional processes, which besides being expensive, involve long periods of time and affect the bioactivity of such compounds. Recently, efforts to develop biotechnological strategies to reduce or eliminate the use of toxic solvents have been reported, reducing processing time and maintaining the bioactivity of the compounds. In this paper, we review, analyze, and discuss methodologies for biotechnological recovery/extraction of flavonoids from agro-industrial residues, describing the advances and challenges in the topic.
\end{abstract}

Keywords: flavonoids; extraction methods; biotransformation; human health

\section{Introduction}

Flavonoids are natural pigments present in the plant or microbial sources and correspond to a specific group of chemical constituents called phenolic compounds [1,2]. They are found in vegetables, seeds, fruit, and various fruits and alcoholic beverages [3]. Flavonoids have important positive effects on human health especially due to their antioxidant and free radical scavenging. Although several studies have shown that some flavonoids have a pro-oxidant effect, they only occur at high doses, most of which confirm the existence of anti-inflammatory effects, antiviral or anti-allergic, and their protective role against cardiovascular disease, cancer, and various pathologies [2,4].

Flavonoids protect the human body from damage caused by oxidizing agents such as ultraviolet rays, environmental pollution, food chemicals, etc. The human organism cannot produce these chemicals in a protective manner, so they must be obtained by means of feed or as supplements. These compounds have been discovered by Nobel Prize winner Szent-György, who in 1930 isolated a 
substance, citrine, which regulates the permeability of the capillaries from the lemon peels. Flavonoids were first identified as vitamin $\mathrm{P}$ (because of the ability to increase capillary permeability) and vitamin C2 (because some flavonoids had similar properties to vitamin C) [1]. However, the fact that flavonoids were vitamins could not be confirmed, and both names remain around 1950. Flavonoids contain in their chemical structure a variable number of phenolic hydroxyl groups and excellent properties of iron chelation and other transition metals, which give them a high antioxidant capacity; therefore, they play an essential role in the protection against oxidative damage and have therapeutic effects in a wide range of conditions, including heart disease ischemic, or atherosclerosis cancer [5-7]. Antifree radical properties of flavonoids are primarily aimed at hydroxyl and superoxide radicals, highly reactive species involved in the onset of lipid chain peroxidation and described their ability to modify eicosanoid synthesis (with antiprostanoid and anti-inflammatory reactions) to prevent platelet aggregation (antithrombotic effects) and to protect low-density lipoproteins from oxidation [8,9].

In addition to its known antioxidant effects, flavonoids have other properties, including stimulation of communication through gap junctions, effects on the regulation of cell growth and induction of enzymes, detoxification such as dependent monooxygenase Cytochrome P-450, among others. [10]. However, most of the biological properties of flavonoids are strongly determined by the mode of extraction for their recovery. Efforts have recently been reported to develop biotechnological strategies to reduce or eliminate the use of toxic solvents, reduce processing time, and maintain the bioactivity of the compounds. This paper examines, analyzes, and discusses the biotechnological methodologies and the recovery/extraction of flavonoids from agro-industrial residues, describing the advances and challenges in the field.

\section{Flavonoids}

Flavonoids are a type of polyphenolic compound, its chemical structure is varied but the general skeleton structure is composed of 15 carbones $\left(\mathrm{C}_{6}-\mathrm{C}_{3}-\mathrm{C}_{6}\right)$, which are grouped in two aromatic rings (A and B) connected by a 3-carbon bridge that gives rise to an oxygenated heterocycle (C) [11-15] (Figure 1). Flavonoids are derivatives of 1,3-diphenylpropan-1-one and their biosynthetic pathway is the condensation of three malonyl-CoA molecules with one $p$-coumaroyl-CoA molecule to the intermediate chalcone $[16,17]$. Flavonoids are water-soluble pigments present in the plant kingdom as secondary plant metabolites [2,18,19], which can be found specifically in the cytosol and stored in the plant cell vacuole [12,17].

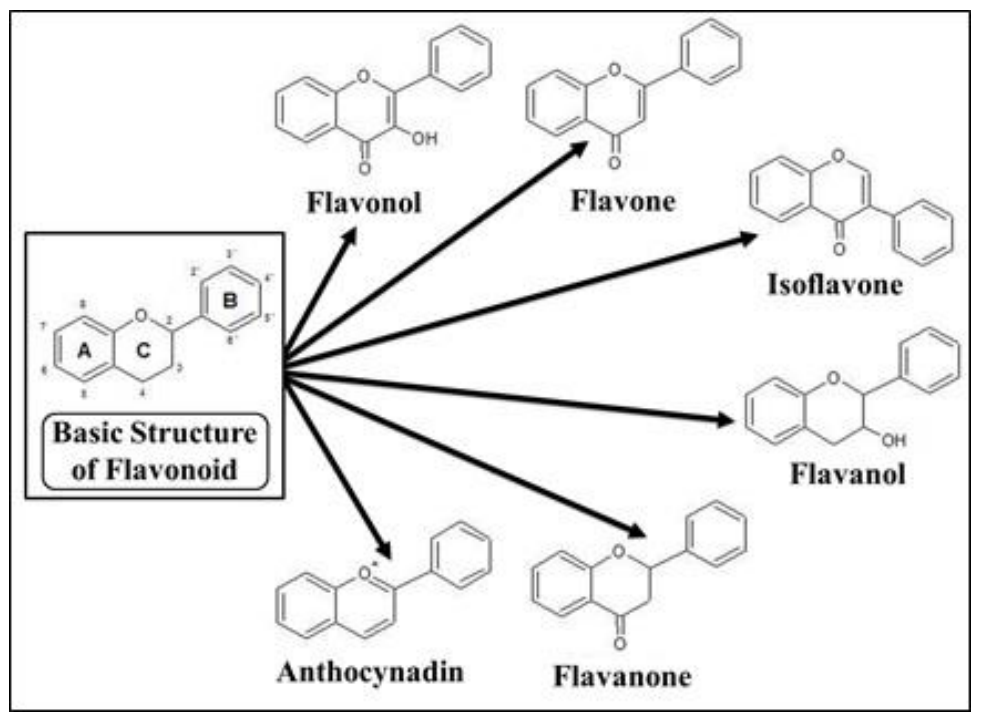

Figure 1. Basic chemical structures of flavonoids and their different class. 
Flavonoids are classified according to differences in the structure of the heterocyclic $\mathrm{C}$ ring; these differences may be caused by the oxidation state and the degree of unsaturation of the heterocyclic ring (or the lack thereof in the case of chalcones). It has been estimated that the number of identified flavonoids exceeds 7000 and that the number of flavonoids continues to increase due to their important biological activities [17]. Variations in the basic structure of flavonoids give rise to six different classes of this group of compounds: Isoflavones, flavanone, flavanone, flavan-3-ol, flavonol, and anthocyanidin, each of which has particular characteristics $[18,20]$.

\subsection{Flavanones}

Flavanones (dihydroflavones) have a structure that differs in the lack of a double bond $\left(C_{2}-C_{3}\right)$ in the C-ring of the flavonoid structure. This type of flavonoid can be found in aromatic plants (such as mint), tomatoes, citrus (especially grapefruit) [12]. Flavanones can be found in nature as forms of aglycones and glycosides, some examples of such compounds are naringenin, hesperetin, and eriodictyol [21].

\subsection{Flavonols}

Flavonols are called 3-hydroxyflavones and are the most commonly found flavonoids in the plant kingdom [22]. A double bond between $C_{2}$ and $C_{3}$ and a hydroxyl group is included in their structures [13]. Some of the most important phytochemical compounds that represent this group are as follows: Myricetin, quercetin, isorhamnetin, and kaempferol [12,22,23]. They can be found in a variety of colors (from white to yellow). In nature, flavonols can be found in two forms: Glycosides and aglycone (quercetin and kaempferol) [12].

\subsection{Flavones}

Flavones can be found in all parts of the plants, above-and belowground, in vegetative and generative organs; stem, leaves, buds, bark, heartwood, thorns, roots, rhizomes, flowers, farina, fruit, seeds, and also in root and leaf exudates or resin. They result from the introduction of a double bond between $C_{2}$ and $C_{3}$ by the abstraction of two hydrogen atoms $[16,18]$. Flavones are present in all major land-plant lineages. The plant species that contain flavones belong to over 70 different families in the plant kingdom [16].

\subsection{Anthocyanins}

Anthocyanins are primarily found in nature in glycosidic form. This type of flavonoid is responsible for plant pigment (such as blue, red, pink, and purple) by the formation of weak covalent bonding complexes with other organic compounds [23,24]. More than 500 anthocyanins have been reported and are the product of methoxylation, hydroxylation, and glycosylation patterns in the B ring. The most representative compounds of this subclass of flavonoids are pelargonidin, cyanidin, and delphinidin [12].

\subsection{Flavanols}

Flavanols (flavan-3-ols) are also called catechins, which have a typical flavonoid structure but have different hydroxylation patterns of rings $\mathrm{A}$ and $\mathrm{B}$ and asymmetrical carbon stereochemistry of ring $C\left(C_{2}\right.$ and $\left.C_{3}\right)[25,26]$. The catechins are classified into two groups; free catechins and esterified catechins [27], and constitute the most complex class of flavonoids due to their size, monomers (catechin), or polymeric forms (condensed tannins) [21]. They can be found as the main ingredient in green tea [12]. 


\subsection{Isoflavones}

Another type of flavonoids, isoflavones are commonly referred to as phytoestrogens due to their considerable estrogen activity. They are characterized by the fusion of their ring $B$ with the $C_{3}$ position of the ring $C[21,28-30]$. They are an important group in a variety of fields, such as medicine, cosmetics, and nutrition. These flavonoids can be found in plants of the Leguminosae family (soybeans, alfalfa sprouts, and red clover leaves) [30,31].

\section{Isolation and Extraction Methods}

There is a general methodology consisting of three stages for the isolation, extraction, and identification of phytochemicals from natural sources. Pretreatment or preparation of a sample is the first step in which the centrifuge, filtration, or drying process and others can be used. In the second stage, the extraction, isolation, and purification of flavonoid compounds from different plant samples are most notably. In this step, phytochemicals are extracted using processes such as soxhlet, maceration, water infusion, supercritical fluid extraction, solid microphase extraction, microwave extraction, ultrasound, autohydrolysis, etc. In the last step, the purified and extracted extracts are normally used for further study by chromatography techniques, usually involving the identification, quantification, and recovery of flavonoid compounds.

Details of each method, such as conventional and emerging methods used by a number of researchers for flavonoid extraction, are given in the following sections:

\subsection{Conventional Methods}

Flavonoid extraction and recovery have been booming over recent years because of population trends in healthier lifestyles and the integration of antioxidants into the diet. Therefore, several methods for extracting flavonoids to increase the extraction yields of these major bioactive compounds have been implemented.

Various extractive methods have been proposed, including maceration, percolation, hydro-distillation, boiling, reflux, soaking, and soxhlet [32]. Soxhlet was the most commonly used method for the extraction of flavonoids due to its simplicity and ease of maintenance, low cost, and lower solvent content compared to other methods such as soaking, boiling, or maceration $[14,33,34]$. Various solvents such as ethanol, methanol, benzene, chloroform, ethyl acetate, etc. have been tested in this extraction method to compare the effect on extraction yields [15,32].

In general, liquid-liquid or solid-liquid extraction is the most widely used process for the extraction of flavonoids. Although maceration and water infusion are conventional extraction processes, they are still used today $[35,36]$. These methodologies have adopted the use of solvents such as ethanol, methanol, acetone and not just water for the extraction of bioactive compounds $[14,37,38]$. These conventional extraction methods are characterized by the use of large amounts of solvent, lower extraction yields, and long extraction times compared to other methods. It has been reported that when extraction methodologies involve heat treatments, degradation in the chemical structures of the extracted flavonoids can result in a reduction in bioactivity [39].

Parameters such as time, particle size, type of solvents, mass to volume ratio, temperature, etc. have been evaluated in conventional extraction methods of flavonoid (Table 1) [40-42]. The nature of the extracting agent (solvent) will affect the type of flavonoid extracted and will directly influence the biological activity of the recovered compounds. Of the solvents tested, ethanol and methanol are the most widely used for the extraction of flavonoids due to higher yields achieved in the recovery of flavonoids $[43,44]$. 
Table 1. Summary of studies of isolation and extraction of flavonoids from different plant sources.

\begin{tabular}{|c|c|c|c|c|c|c|c|c|}
\hline Type & Substrate & Solvent & $\begin{array}{c}\text { Temperature } \\
\left({ }^{\circ} \mathrm{C}\right)\end{array}$ & Time & Analysis & Yields & $\begin{array}{c}\text { Bioactivities/ } \\
\text { Bioactives }\end{array}$ & References \\
\hline ASE & $\begin{array}{c}\text { Impatiens } \\
\text { glandulifera } \\
\text { (roots) }\end{array}$ & Methanol (80\%) & 80 & $\begin{array}{l}30 \\
\min \end{array}$ & LC-MS & $\begin{array}{c}257.34 \mu \mathrm{g} \mathrm{PAC} / \mathrm{g} \\
\text { of } \mathrm{dw}\end{array}$ & $\begin{array}{l}\text { Phenolic acid } \\
\text { content }\end{array}$ & [45] \\
\hline ASE & $\begin{array}{l}\text { Impatiens } \\
\text { glandulifera } \\
\text { (flowers) }\end{array}$ & Methanol (80\%) & 80 & $\begin{array}{l}30 \\
\min \end{array}$ & LC-MS & $\begin{array}{c}188.86 \mu \mathrm{g} \mathrm{PAC} / \mathrm{g} \\
\text { of } \mathrm{dw}\end{array}$ & $\begin{array}{l}\text { Phenolic acid } \\
\text { content }\end{array}$ & [45] \\
\hline ASE & Broccoli & $\begin{array}{c}\text { Acetone/water/ } \\
\text { acetic acid } \\
(70: 29,5: 0.5 v / v / v)\end{array}$ & $70-80$ & $5 \mathrm{~min}$ & - & $\begin{array}{c}3377 \pm 62 \mathrm{mg} \\
\text { GAE/100 g edp }\end{array}$ & AoA & [46] \\
\hline ASE & $\begin{array}{l}\text { Cabbage } \\
\text { common }\end{array}$ & $\begin{array}{c}\text { Acetone/water/ } \\
\text { acetic acid } \\
(70: 29,5: 0.5 v / v / v)\end{array}$ & $70-80$ & $5 \mathrm{~min}$ & - & $\begin{array}{c}2037 \pm 31 \mathrm{mg} \\
\text { GAE/100 g edp }\end{array}$ & AoA & [46] \\
\hline ASE & Cabbage red & $\begin{array}{c}\text { Acetone/water/ } \\
\text { acetic acid } \\
(70: 29,5: 0.5 v / v / v)\end{array}$ & $70-80$ & $5 \mathrm{~min}$ & - & $\begin{array}{c}2547 \pm 18 \mathrm{mg} \\
\text { GAE/100 g edp }\end{array}$ & AoA & [46] \\
\hline ASE & Cauliflower & $\begin{array}{c}\text { Acetone/water/ } \\
\text { acetic acid } \\
(70: 29,5: 0.5 v / v / v)\end{array}$ & $70-80$ & $5 \mathrm{~min}$ & - & $\begin{array}{l}274 \text { mg GAE/100 } \\
\text { g edp }\end{array}$ & AoA & [46] \\
\hline ASE & Lepidium sativum & Ethanol $(96 \%)$ & 50 & $5 \mathrm{~min}$ & GC-MS & $\begin{array}{c}58 \mathrm{mg} \mathrm{RuE} / \mathrm{g} \mathrm{dm} \\
\text { of flavonoid } \\
\text { content }\end{array}$ & $\mathrm{AmA}$ and $\mathrm{CtA}$ & [47] \\
\hline ASE & $\begin{array}{l}\text { Impatiens } \\
\text { glandulifera } \\
\text { (leaves) }\end{array}$ & Methanol (80\%) & 80 & $\begin{array}{l}30 \\
\min \end{array}$ & LC-MS & $\begin{array}{c}244.73 \mu \mathrm{g} \text { PAC/g } \\
\text { of dw }\end{array}$ & $\begin{array}{l}\text { Phenolic acid } \\
\text { content }\end{array}$ & [45] \\
\hline HWE & $\begin{array}{l}\text { Pine (Pinus rigida } \\
\times \text { taedaand Pinus } \\
\text { koraiensis) bark }\end{array}$ & Boiling water & 100 & $1 \mathrm{~h}$ & - & $\begin{array}{l}111-862 \mathrm{mg} \\
\mathrm{CAE} / \mathrm{g} \mathrm{dw}\end{array}$ & AoA & [48] \\
\hline Maceration & Broccoli & $\begin{array}{l}\text { Acetone/water } \\
(70: 30 v / v)\end{array}$ & 4 & $24 \mathrm{~h}$ & LC-MS & $\begin{array}{c}82.2 \pm 8.9 \mathrm{mg} \\
\text { GAE/100 g edp }\end{array}$ & AoA & [49] \\
\hline Maceration & Cauliflower & $\begin{array}{l}\text { Acetone/water } \\
(70: 30 v / v)\end{array}$ & 4 & $24 \mathrm{~h}$ & LC-MS & $\begin{array}{l}27.8 \pm 71.5 \mathrm{mg} \\
\mathrm{GAE} / 100 \mathrm{~g} \text { edp }\end{array}$ & AoA & [49] \\
\hline Maceration & Chinese cabbage & $\begin{array}{l}\text { Acetone/water } \\
(70: 30 \mathrm{v} / \mathrm{v})\end{array}$ & 4 & $24 \mathrm{~h}$ & LC-MS & $\begin{array}{l}118.9 \pm 712.5 \mathrm{mg} \\
\text { GAE/100 g edp }\end{array}$ & AoA & [49] \\
\hline Maceration & White cabbage & $\begin{array}{c}\text { Acetone/water } \\
(70: 30 v / v)\end{array}$ & 4 & $24 \mathrm{~h}$ & LC-MS & $\begin{array}{l}15.37 \pm 2.1 \mathrm{mg} \\
\text { GAE/100 g edp }\end{array}$ & AoA & [49] \\
\hline Maceration & Broccoli & $\begin{array}{l}\text { Acetone/water } \\
(80: 20 v / v)\end{array}$ & $\begin{array}{c}\text { Room } \\
\text { temperature }\end{array}$ & $8 \mathrm{~min}$ & - & $\begin{array}{l}80.87 \pm 1.2 \mathrm{mg} \\
\text { GAE/100 g edp }\end{array}$ & AoA and ApA & [50] \\
\hline Maceration & Cabbage & $\begin{array}{c}\text { Acetone/water } \\
(80: 20 v / v)\end{array}$ & $\begin{array}{c}\text { Room } \\
\text { temperature }\end{array}$ & $8 \mathrm{~min}$ & - & $\begin{array}{l}36.77 \pm 6.9 \mathrm{mg} \\
\mathrm{GAE} / 100 \mathrm{~g} \text { edp }\end{array}$ & AoA and ApA & [50] \\
\hline Maceration & Broccoli & $\begin{array}{l}\text { Methanol/water } \\
(80 / 20 v / v)\end{array}$ & $\begin{array}{c}\text { Room } \\
\text { temperature }\end{array}$ & - & - & $\begin{array}{c}34.571 .0 \mathrm{mg} \\
\text { GAE/100 g edp }\end{array}$ & AoA & [51] \\
\hline Maceration & $\begin{array}{c}\text { Solanum scabrum } \\
\text { leaves }\end{array}$ & Acetone & - & $72 \mathrm{~h}$ & - & $34.2 \mathrm{~g} \mathrm{GAE} / 100 \mathrm{~g}$ & AoA & [52] \\
\hline Maceration & Lepidium sativum & Ethanol (96\%) & 50 & $24 \mathrm{~h}$ & GC-MS & 25 mg RuE/g dw & $\mathrm{AmA}$ and $\mathrm{CtA}$ & [47] \\
\hline Maceration & Banana & Water & - & - & - & $\begin{array}{c}8.51 \mu \mathrm{g} \text { QuE/g } \\
\mathrm{dw}\end{array}$ & AoA & [42] \\
\hline Maceration & Pitanga & $\begin{array}{l}\text { Ethanol }(75 \%) \\
\text { and Hexane }\end{array}$ & 25 & $4 \mathrm{~h}$ & - & $\begin{array}{c}232.2 \mathrm{mg} \mathrm{GAE} / \mathrm{g} \\
\text { and } 12.4 \mathrm{mg} \\
\mathrm{GAE} / \mathrm{g} \mathrm{dw}, \\
\text { respectively }\end{array}$ & AoA and $\mathrm{AbA}$ & [53] \\
\hline Maceration & $\begin{array}{c}\text { Artocarpus } \\
\text { heterophyllus } \\
\text { wastes }\end{array}$ & $\begin{array}{c}\text { Ethanol }(70 \%) \\
\text { and ethanol pure }\end{array}$ & 25 & $72 \mathrm{~h}$ & LC-MS & $\begin{array}{c}871.4 \mathrm{mg} \mathrm{QuE} / \mathrm{g} \\
\mathrm{dw}\end{array}$ & AoA & [44] \\
\hline Maceration & $\begin{array}{l}\text { Kinnow } \\
\text { mandarin }\end{array}$ & Methanol (80\%) & - & - & LC-MS & $\begin{array}{c}28.40 \mathrm{mg} \mathrm{GAE} / \mathrm{g} \\
\mathrm{dw}\end{array}$ & AoA and AmA & [41] \\
\hline Maceration & $\begin{array}{l}\text { Apple tree wood } \\
\text { residues }\end{array}$ & $50 \%$ Ethanol & 55 & $2 \mathrm{~h}$ & LC-PdAD & $\begin{array}{c}43.2 \mathrm{mg} \mathrm{GAE} / \mathrm{g} \\
\mathrm{dw}\end{array}$ & $\begin{array}{c}\text { Food, } \\
\text { pharmaceutical } \\
\text { and } \\
\text { cosmeticapplications }\end{array}$ & [54] \\
\hline Maceration & $\begin{array}{c}\text { Pinus radiata } \\
\text { bark }\end{array}$ & $\begin{array}{c}\text { Acetone:water } \\
\text { 70:30 v/v }\end{array}$ & 40 & $\begin{array}{l}180 \\
\min \end{array}$ & - & $\begin{array}{l}412 \pm 0 \mathrm{mg} \\
\mathrm{CAE} / \mathrm{g}\end{array}$ & ArA & [55] \\
\hline Maceration & $\begin{array}{l}\text { Quercus (Q. robur } \\
\text { L.) bark }\end{array}$ & Water & 25 & $\begin{array}{l}120 \\
\min \end{array}$ & - & $\begin{array}{c}3.7 \pm 0.6 \mathrm{mg} \\
\mathrm{GAE} / \mathrm{g}\end{array}$ & $\mathrm{AoA}$ and $\mathrm{AbA}$ & [56] \\
\hline Maceration & $\begin{array}{l}\text { Chokeberry } \\
\text { (Aronia } \\
\text { melanocarpa) }\end{array}$ & $\begin{array}{l}50 \% \text { Ethanol. } \\
\text { Ratio 1:20 }\end{array}$ & $\begin{array}{l}\text { Ambient } \\
\text { temperature }\end{array}$ & $\begin{array}{l}60 \\
\min \end{array}$ & LC-MS & $\begin{array}{c}27.7 \mathrm{mg} \mathrm{GAE} / \mathrm{g} \\
\mathrm{dw}\end{array}$ & $\begin{array}{l}\text { Extraction of } \\
\text { bioactive } \\
\text { compounds }\end{array}$ & [35] \\
\hline
\end{tabular}


Table 1. Cont.

\begin{tabular}{|c|c|c|c|c|c|c|c|c|}
\hline Type & Substrate & Solvent & $\begin{array}{c}\text { Temperature } \\
\left({ }^{\circ} \mathrm{C}\right)\end{array}$ & Time & Analysis & Yields & $\begin{array}{c}\text { Bioactivities/ } \\
\text { Bioactives }\end{array}$ & References \\
\hline Percolation & $\begin{array}{c}\text { Artocarpus } \\
\text { heterophyllus } \\
\text { wastes }\end{array}$ & Ethanol $(70 \%)$ & 25 & $1 \mathrm{~h}$ & LC-MS & $\begin{array}{c}511.6 \underset{\mathrm{mg} \mathrm{QuE} / \mathrm{g}}{\mathrm{dw}} \\
\text { (1) }\end{array}$ & AoA & [44] \\
\hline Reflux & $\begin{array}{c}\text { Portulaca oleracea } \\
\text { L. }\end{array}$ & $\begin{array}{c}\text { Ethanol-water } \\
(70: 30, v / v)\end{array}$ & - & $\begin{array}{l}150 \\
\min \end{array}$ & - & $6.8 \mathrm{mg} \mathrm{RuE} / \mathrm{g}$ & $\begin{array}{c}\text { Flavonoid } \\
\text { content }\end{array}$ & [57] \\
\hline SDE & $\begin{array}{l}\text { Dried leaves of } \\
\text { basil (Ocimum } \\
\text { basilicum L.), and } \\
\text { epazote } \\
\text { (Chenopodium } \\
\text { ambrosioides L.). }\end{array}$ & Water & - & $\begin{array}{l}30 \\
\min \end{array}$ & GC-MS & $\begin{array}{c}0.47 \text { y } 0.39 \% \\
\text { yield of EO from } \\
\text { basil and } \\
\text { epazote }\end{array}$ & $\begin{array}{l}\text { Essential oil } \\
\text { extraction }\end{array}$ & [59] \\
\hline Soxhlet & $\begin{array}{c}\text { Buddleia } \\
\text { officinalis Maxim }\end{array}$ & Ethanol (95\%) & - & $2 \mathrm{~h}$ & - & $\begin{array}{c}62.56 \mathrm{mg} \mathrm{CAE} / \mathrm{g} \\
\mathrm{dw}\end{array}$ & AoA & [61] \\
\hline Soxhlet & $\begin{array}{l}\text { Morus nigra } \\
\text { (dried) }\end{array}$ & Petroleum ether & 50 & $3 \mathrm{~h}$ & - & $\begin{array}{c}58.94 \% \text { of } \\
\text { flavonoid yield }\end{array}$ & AoA & [62] \\
\hline Soxhlet & $\begin{array}{l}\text { Fresh leaves of } \\
\text { Vernoniaamygdalina }\end{array}$ & Water & 100 & $8 \mathrm{~h}$ & GC-MS & - & AoA & [63] \\
\hline Soxhlet & $\begin{array}{l}\text { Vernonia cinerea } \\
\text { leaves }\end{array}$ & Ethanol (60\%) & - & $2 \mathrm{~h}$ & LC-Q-TOF- & MS.22 mg QuE/g & AoA & [32] \\
\hline Soxhlet & $\begin{array}{c}\text { Artocarpus } \\
\text { heterophyllus } \\
\text { wastes }\end{array}$ & $\begin{array}{l}\text { Ethanol (70\% } \\
\text { and pure) }\end{array}$ & Boiling point & $5 \mathrm{~h}$ & LC-MS & $\begin{array}{c}381.4 \mathrm{mg} \mathrm{QuE} / \mathrm{g} \\
\mathrm{dw}\end{array}$ & AoA & [44] \\
\hline Soxhlet & $\begin{array}{l}\text { Impatiens } \\
\text { glandulifera } \\
\text { (flowers) }\end{array}$ & $\begin{array}{l}\text { Chloroform, } 80 \% \\
\text { Methanol and } \\
\text { pure Methanol }\end{array}$ & - & $72 \mathrm{~h}$ & LC-MS & $\begin{array}{c}188.07 \mathrm{mg} \text { PAC/g } \\
\mathrm{dw}\end{array}$ & AoA & [45] \\
\hline Soxhlet & $\begin{array}{l}\text { Pinus radiata } \\
\text { bark }\end{array}$ & $\begin{array}{l}\text { Acetone:water } \\
70: 30 v / v\end{array}$ & 82 & $\begin{array}{l}60, \\
120, \\
180, \\
\text { and } \\
360 \\
\text { min }\end{array}$ & - & $\begin{array}{c}622 \pm 40 \mathrm{mg} \\
\mathrm{CAE} / \mathrm{g}\end{array}$ & ArA & [55] \\
\hline Soxhlet & $\begin{array}{c}\text { Spearmint } \\
\text { (Mentha spicata } \\
\text { L.) }\end{array}$ & Methanol & 40 & $6 \mathrm{~h}$ & HPLC & $\begin{array}{c}0.144 \mathrm{mg} \mathrm{CAE} / \mathrm{g} \\
\mathrm{dw}\end{array}$ & $\begin{array}{l}\text { Flavonoid } \\
\text { extraction }\end{array}$ & [64] \\
\hline Soxhlet & $\begin{array}{c}\text { Knotwood } \\
\text { (Populus tremula) }\end{array}$ & Methanol & - & $48 \mathrm{~h}$ & LC-MS & $11.5 \mathrm{mg} / \mathrm{g}$ & $\begin{array}{l}\text { Flavonoid } \\
\text { extraction }\end{array}$ & [65] \\
\hline
\end{tabular}

Abbreviations: AbA: Antibacterial activity; AmA: Antimicrobial activity; AoA: Antioxidant activity; ApA: Antiproliferative activities; ArA: Antiradical activity; ASE: Accelerated solvent extraction; CAE: Catechin equivalents; CtA: Cytotoxicity activity; dm: Dry matter; dw: Dry weight; edp: Edible portion; ESI: Electrospray ion source; GAE: Gallic acid equivalents; GC-MS: Gas chromatography mass spectrometer; HPLC: High performance liquid chromatography; HWE: Hot water extraction; LC: Liquid chromatography; LC-MS: Liquid chromatography mass spectrometer; MS: Mass spectrometer; PAC: Phenolic acid content; PdAD: Photodiode array detector; Q-TOF: Quadrupole-time of flight; QuE: Quercetin equivalents; RSISE: Rotary solid-liquid solvent extraction as Traditional Method; RuE: Rutin equivalents; SDE: Steam distillation extraction; SIE: Solid-liquid extraction; TPC: Total phenolic content.

The high demand for antioxidants gave way to the search for methodological alternatives that would increase the yield of flavonoid extraction and reduce process costs. In addition, it has been found that the methodologies implemented are cleaner and environmentally friendly. 


\subsection{Emerging and Advanced Methods}

Two of the most widely used techniques for the extraction of flavonoids are emerging microwave (MAE) and ultrasound-assisted extraction (UAE) technologies. Table 2 shows some of the published works on the extraction of flavonoids using these emerging methods.

Table 2. Studies on emerging methods of isolation and extraction of flavonoids from different plant sources.

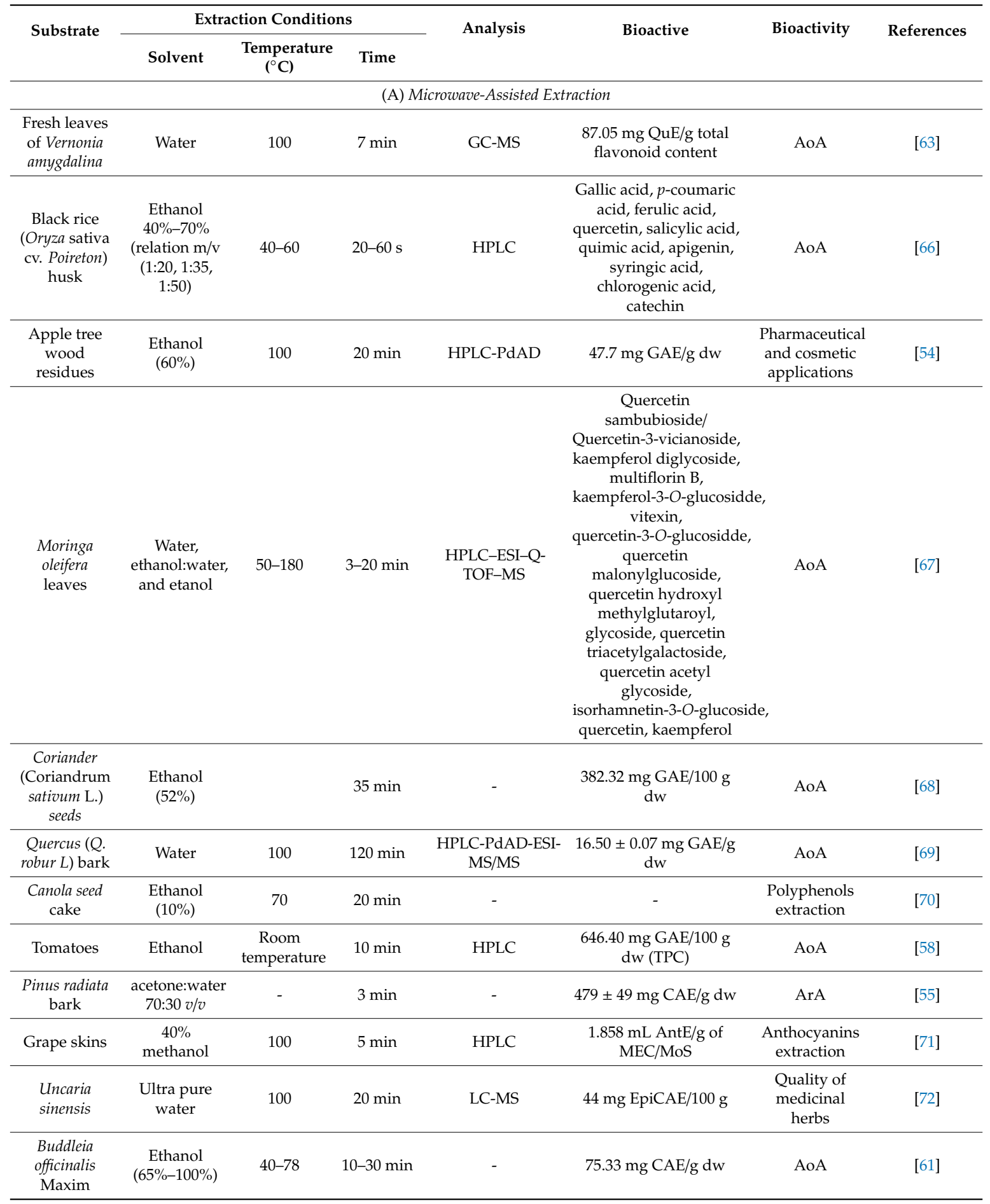


Table 2. Cont.

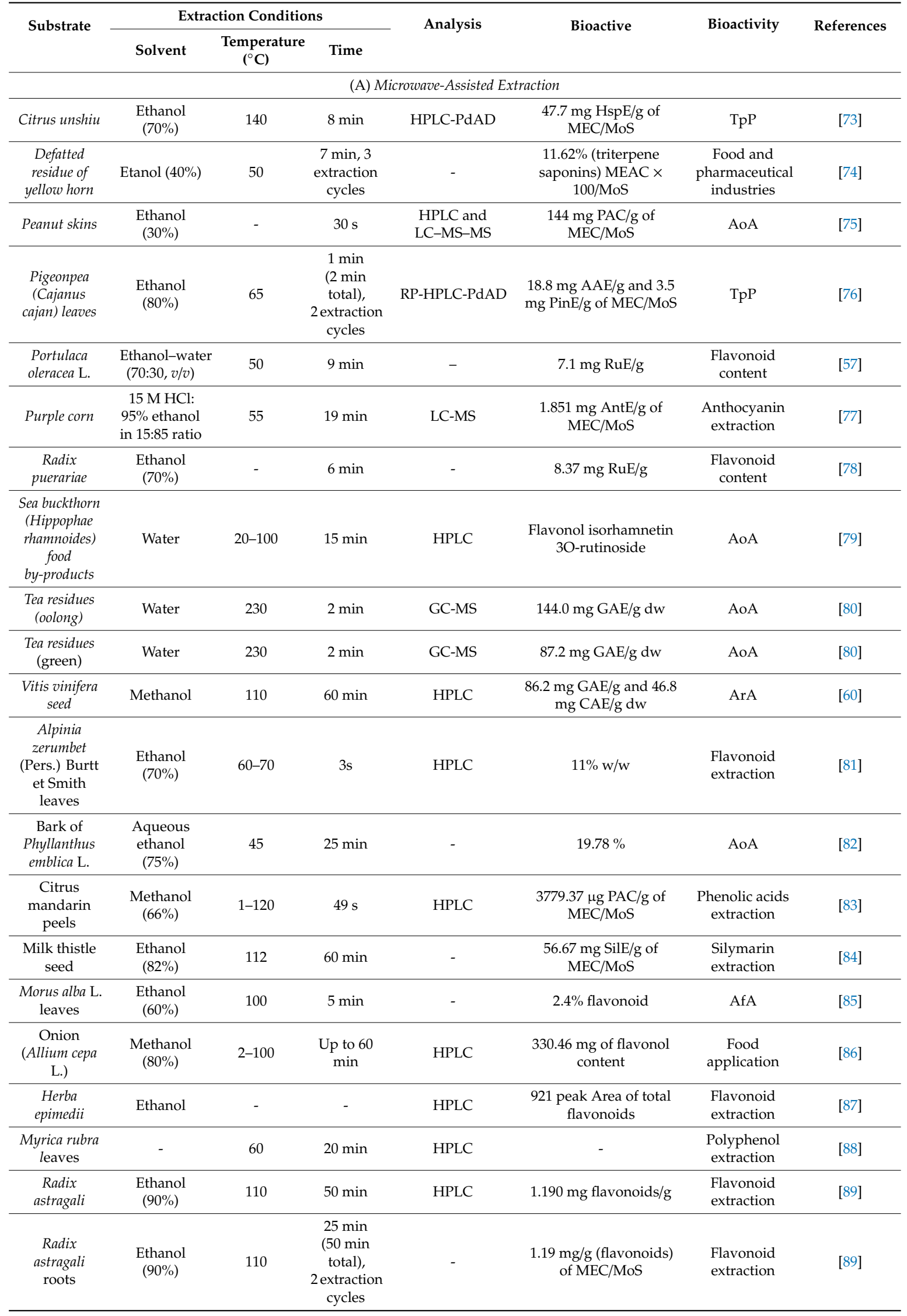


Table 2. Cont.

\begin{tabular}{|c|c|c|c|c|c|c|c|}
\hline \multirow{2}{*}{ Substrate } & \multicolumn{3}{|c|}{ Extraction Conditions } & \multirow{2}{*}{ Analysis } & \multirow{2}{*}{ Bioactive } & \multirow{2}{*}{ Bioactivity } & \multirow{2}{*}{ References } \\
\hline & Solvent & $\begin{array}{l}\text { Temperature } \\
\left({ }^{\circ} \mathrm{C}\right)\end{array}$ & Time & & & & \\
\hline $\begin{array}{l}\text { Platycladus } \\
\text { orientalis } \\
\text { leaves }\end{array}$ & $\begin{array}{l}\text { Methanol } \\
(80 \%)\end{array}$ & - & $5 \mathrm{~min}$ & - & $\begin{array}{l}1.72 \% \text { (flavonoids) } \\
\text { MEAC } \times 100 / \mathrm{MoS}\end{array}$ & $\begin{array}{l}\text { Flavonoid } \\
\text { extraction }\end{array}$ & [90] \\
\hline Olive leaves & $\begin{array}{c}\text { Ethanol } \\
(80 \%)\end{array}$ & - & $8 \mathrm{~min}$ & HPLC- PdAD & $\begin{array}{c}\text { 95\% (oleuropein) } \\
\text { MEAC × 100/MTACCS }\end{array}$ & $\begin{array}{l}\text { Biophenols } \\
\text { extraction }\end{array}$ & {$[92]$} \\
\hline $\begin{array}{l}\text { Acanthopanax } \\
\text { senticosusleaves }\end{array}$ & $\begin{array}{c}\text { Ethanol } \\
(50 \%)\end{array}$ & & $10 \mathrm{~min}$ & ESI-MS & - & $\begin{array}{l}\text { Flavonoid } \\
\text { extraction }\end{array}$ & [93] \\
\hline $\begin{array}{l}\text { Capsicum } \\
\text { fruit }\end{array}$ & Acetone & - & $15 \mathrm{~min}$ & GC-MS & $0.48 \mathrm{mg} \mathrm{CpE} / \mathrm{g} \mathrm{fw}$ & Food aditives & [95] \\
\hline \multicolumn{8}{|c|}{ (B) Ultrasound-Assisted Extraction } \\
\hline $\begin{array}{l}\text { Dysphania } \\
\text { ambrosioides } \\
\text { (L) }\end{array}$ & $\begin{array}{c}\text { Ethanol } \\
(57 \% \mathrm{w} / \mathrm{w})\end{array}$ & 57 & $60 \mathrm{~min}$ & - & $\begin{array}{l}1.09 \% \text { of flavonoids } \\
\text { equivalents of rutin }\end{array}$ & $\begin{array}{l}\text { Flavonoid } \\
\text { extraction }\end{array}$ & [96] \\
\hline $\begin{array}{l}\text { Lepidium } \\
\text { satioum } \\
\text { seeds }\end{array}$ & Ethanol & 50 & $24 \mathrm{~h}$ & GC-MS & $97 \mathrm{mg} \mathrm{GAE} / \mathrm{g} \mathrm{dm}$ & $\mathrm{AmA}$ and $\mathrm{CtA}$ & [47] \\
\hline $\begin{array}{l}\text { Impatiens } \\
\text { glandulifera } \\
\text { (leaves) }\end{array}$ & $\begin{array}{l}\text { Methanol } \\
(80 \%)\end{array}$ & 30 & $60 \mathrm{~min}$ & LC-MS & $291.55 \mu \mathrm{g} / \mathrm{g} \mathrm{dw}$ & AoA & [45] \\
\hline $\begin{array}{l}\text { Impatiens } \\
\text { glandulifera } \\
\text { (roots) }\end{array}$ & $\begin{array}{l}\text { Methanol } \\
(80 \%)\end{array}$ & 30 & $60 \mathrm{~min}$ & LC-MS & $286.04 \mu \mathrm{g} / \mathrm{g} \mathrm{dw}$ & AoA & [45] \\
\hline $\begin{array}{l}\text { Kinnow } \\
\text { mandarin }\end{array}$ & $\begin{array}{l}\text { Ethanol } \\
(80 \%)\end{array}$ & $35,45,55$ & $40-70 \mathrm{~min}$ & HPLC & $28.40 \mathrm{mg} \mathrm{GAE} / \mathrm{g}$ extract & $\begin{array}{l}\text { AoA and } \\
\text { AmA }\end{array}$ & [41] \\
\hline $\begin{array}{l}\text { Nephelium } \\
\text { lappaceum } \\
\text { L.fruit peel }\end{array}$ & $\begin{array}{l}\text { Solid-liquid } \\
\text { ratio } 1: 18.6 \\
\text { g/mL }\end{array}$ & 50 & $20 \mathrm{~min}$ & - & $\begin{array}{c}10.26 \pm 0.69 \mathrm{mg} \\
\text { AntE/100 g; } 552.64 \pm \\
1.57 \mathrm{mg} \text { GAE } / 100 \mathrm{~g} ; 104 \\
\pm 1.13 \mathrm{mg} \mathrm{RuE} / 100 \mathrm{~g}\end{array}$ & $\begin{array}{l}\text { Flavonoid } \\
\text { extraction }\end{array}$ & [98] \\
\hline $\begin{array}{l}\text { Curry leaf } \\
\text { (Murraya } \\
\text { koenigii L.) }\end{array}$ & $\begin{array}{l}\text { Methanol } \\
80 \% 55.9 \% \\
145.49 \mathrm{~W} \\
\end{array}$ & 55.9 & - & UHP-LC & $\begin{array}{c}0.482 \mathrm{mg} \mathrm{CAE} / \mathrm{g} \mathrm{dw} ; \\
0.517 \mathrm{mg} \mathrm{NrgE} / \mathrm{g} \mathrm{dw} ; \\
0.394 \mathrm{mg} \mathrm{QuE} / \mathrm{g} \mathrm{dw}\end{array}$ & $\begin{array}{l}\text { Pharmaceutical } \\
\text { application }\end{array}$ & [99] \\
\hline $\begin{array}{l}\text { Portulaca } \\
\text { oleracea L }\end{array}$ & $\begin{array}{l}\text { Ethanol } \\
39.01 \%\end{array}$ & 55.25 & $15 \mathrm{~min}$ & - & $16.25 \mathrm{mg} \mathrm{RuE} / \mathrm{g} \mathrm{dw}$ & - & [100] \\
\hline $\begin{array}{l}\text { Pinus radiata } \\
\text { bark }\end{array}$ & $\begin{array}{c}\text { acetone:water } \\
70: 30 v / v\end{array}$ & - & $3-12 \min$ & - & $388 \pm 7$ mg CAE/g bark & ArA & [55] \\
\hline $\begin{array}{c}\text { Morus } \\
\text { laevigata W. } \\
\text { M. alba } \mathrm{L} . \\
\text { and M. nigra } \\
\text { L }\end{array}$ & $\begin{array}{l}\text { Methanol } \\
(80 \%)\end{array}$ & - & - & HPLC & $\begin{array}{c}3.89 \text { to } 11.79 \mu \mathrm{moL} \\
\mathrm{GAE} / 100 \mathrm{~g}\end{array}$ & AoA & [101] \\
\hline
\end{tabular}


Table 2. Cont.

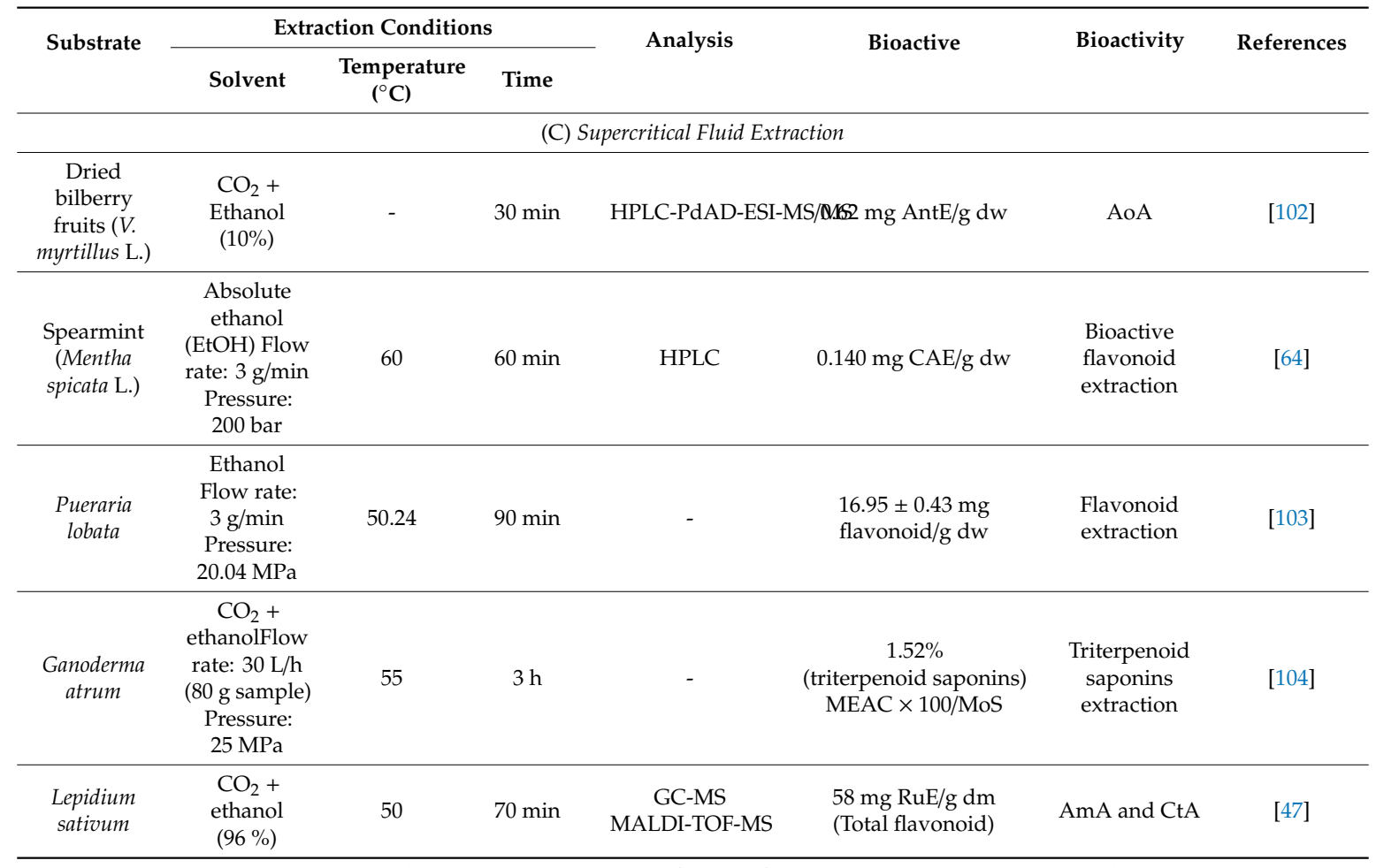

Abbreviations: AAE: Ajaninstilbene acid equivalents; AfA: Antifatigue activity; AmA: Antimicrobial activity; AntE: Anthocyanins equivalents; AoA: Antioxidant activity; ArA: Antiradical activity; CAE: Catechin equivalents; CpE: Capsaicin equivalents; CtA: Cytotoxicity activity; dm: Dry matter; dw: Dry weight; EpiCAE: Epicatechin equivalents; ESI: Electrospray ion source; GAE: Gallic acid equivalents; GC-MS: Gas chromatography mass spectrometer; HPLC: High performance liquid chromatography; HspE: Hesperidin equivalents; LC: Liquid chromatography; LC-MS: Liquid chromatography mass spectrometer; MAE: Microwave assisted extraction; MALDI: Matrix-assisted laser desorption ionization; MEAC: Mass of extracted active compound; MEC: Mass of extracted compound; MoS: Mass of sample; MS: Mass spectrometer; MTACcS: Mass of total active compound content in the sample; NrgE: Narengine equivalents; PAC: Phenolic acid content; PdAD: Photodiode array detector; PinE: Pinostrobin equivalents; Q-TOF: Quadrupole-time of flight; QuE: Quercetin equivalents; RP: Reversed-phase; RuE: Rutin equivalents; SilE: Silymarin equivalents; TOF: Time of flight; TPC: Total phenolic content; TpP: Therapeutic potential; UHP: Ultra high performance.

\subsubsection{Microwave-Assisted Extraction}

Microwave is an electromagnetic spectrum of radiation ranging from $300 \mathrm{MHz}$ (radio radiation) to $300 \mathrm{GHz}$ (infrared radiation). This heating technique uses microwave energy and is based on the direct effect of microwaves on dipole polarization and ion conduction molecules [105-107] (Figure 2). The extraction of flavonoids may be affected by a large number of parameters, among the most important of which are: Time, temperature, plant material-solvent ratio, solvent concentration, solvent polarity, irradiation, frequency of intensity, and microwave power [63,106,108-110].

It has been reported that MAE allows for a significant reduction in the extraction times of a wide variety of compounds, also reduces the volumes of solvents used, and it has been shown that the extraction yields of bioactive compounds are superior to conventional methods such as maceration, Soxhlet, or heat reflux $[66,106,112,113]$. Reduction of extraction times and the use of solvents are employed to improve the cost of extraction [39]. 


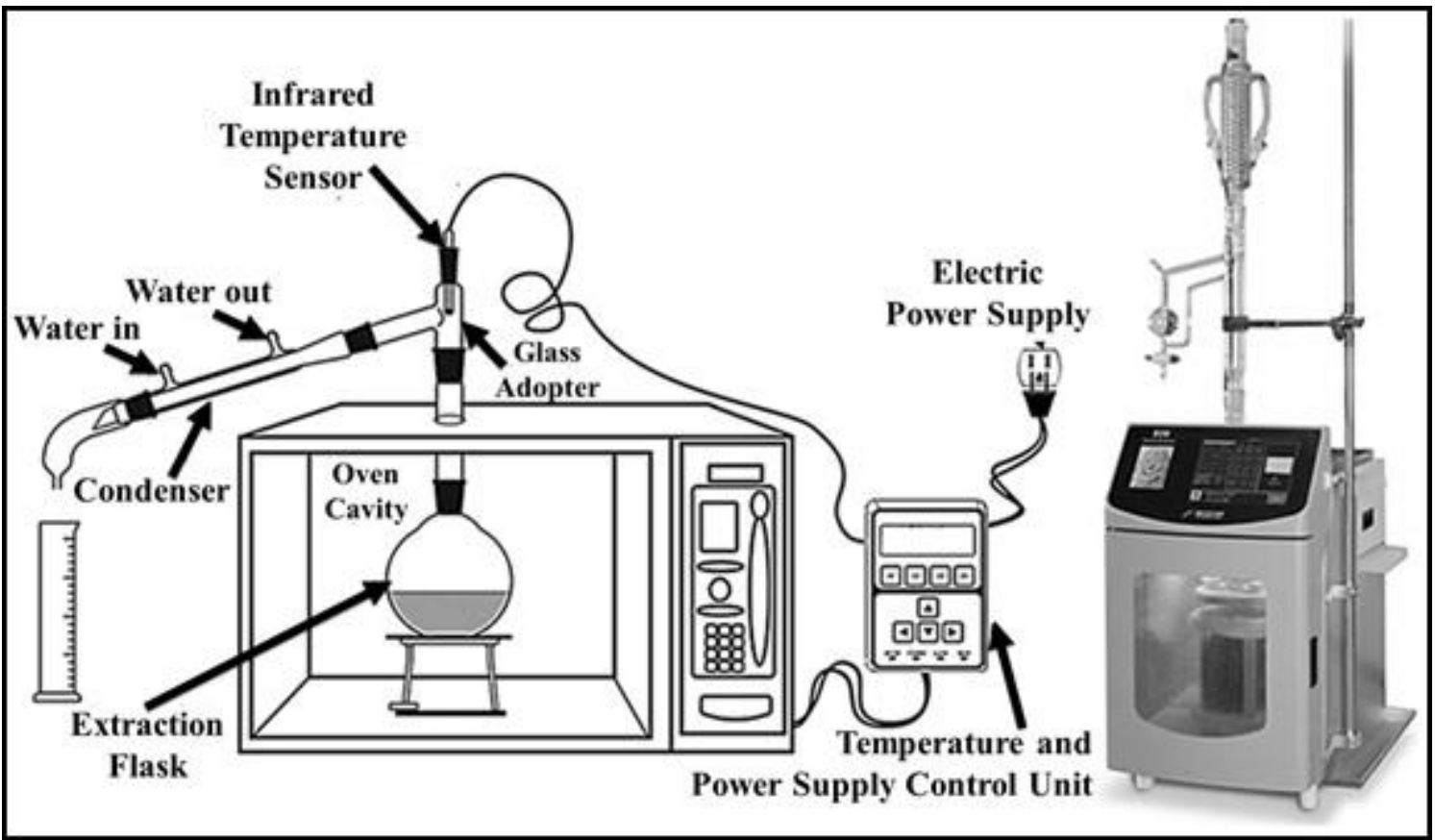

Figure 2. Schematic setup of microwave-assisted extraction (MAE) [111].

The choice of solvent is not only important in this methodology; the dielectric properties of the solvent must be taken into account [106]. The most commonly used solvents for MAE are ethanol and methanol, both of which have shown the best extraction yields, although water has also shown positive effects $[66,68,107]$. The efficacy of MAE will also depend on the type of flavonoid to be recovered. For example, the polarity of the flavonoid will be a very important parameter to consider; the type of solvent used will be the polarity of the desired recovery. Moreover, the solvent used in the extraction process may have an effect on the bioactivity of the recovered flavonoids [66]. Apolar solvents such as dichloromethane, ethyl acetate, diethyl ether, chloroform are commonly used for the extraction of isoflavones, flavones, and methylated flavones due to their apolar nature. In contrast, solvents such as ethanol or methanol are used to extract polar flavonoids such as flavonoid glycosides and aglycones (Table 2A).

\subsubsection{Ultrasound-Assisted Extraction}

Ultrasound-assisted extraction is a technique that is used to rupture the plant material and extract the bioactive compounds with applications in industries such as food and pharmaceuticals [108]. This technique is based on the phenomenon of acoustic cavitation, which consists of the formation of bubbles and the subsequent rupture, which causes the release of bioactive compounds, and this rupture depends on the extraction conditions [97,114] (Figure 3).

The cavitation effect produced by this methodology not only enables the destruction of the cell walls of the plant material but also promotes the reduction of the particle size that benefits the solvent-substrate interaction [97]. There are many variables that can have an effect on flavonoid extractive processes and therefore on the number of experiments; in order to optimize a particular process, experimental matrices are usually used to perform the optimization process in order to determine the conditions that favor the recovery of the maximum flavonoid content. Most of the published works have opted to use the surface response methodology to achieve this objective [63]. 


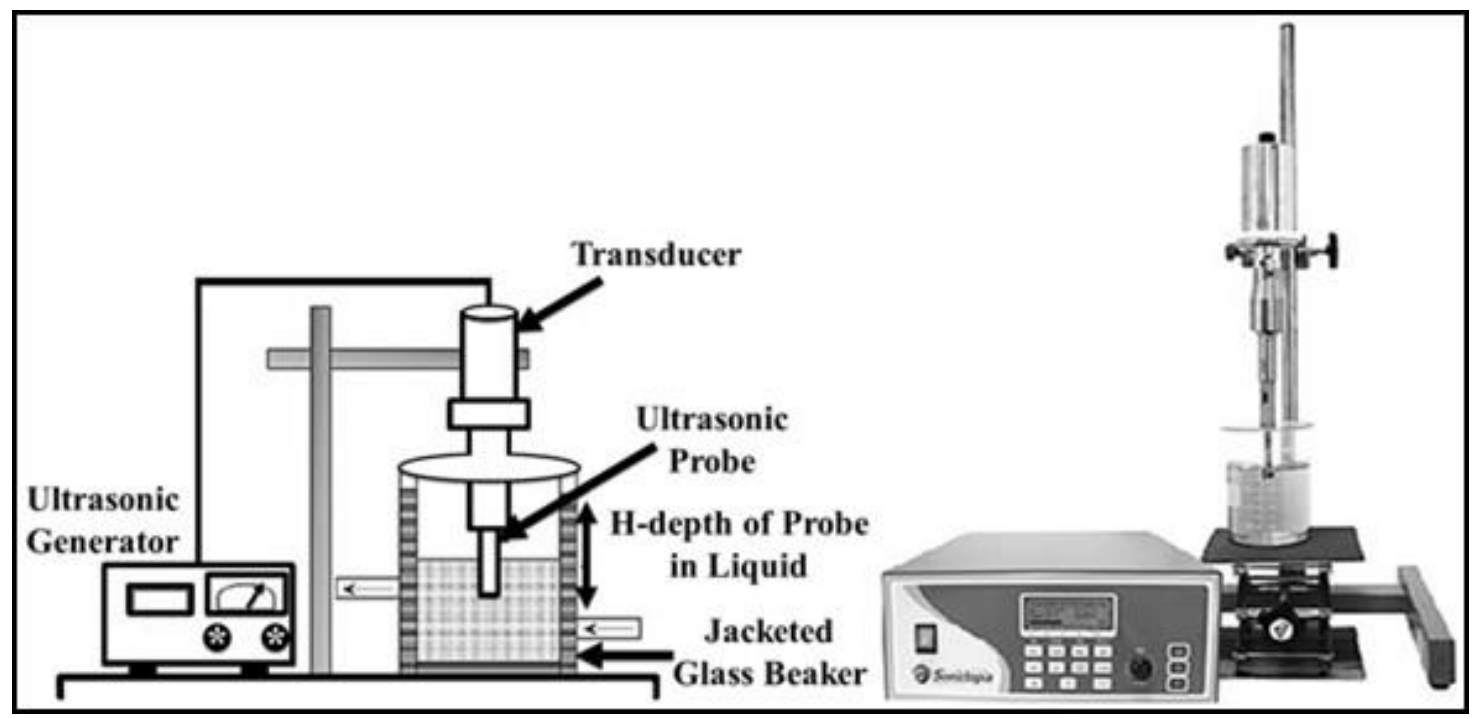

Figure 3. Schematic setup of ultrasound-assisted extraction (UAE) [111].

The UAE increased the yield of bioactive compounds and the yield of flavonoids were shown to be variable depending on the method of extraction, as well as on the type of plant material (Table 2B). Mainly phenolic compounds and flavonoids, as well as the reduction of extraction times, and another of the advantages of this methodology is that it improves the biological properties of the extracts [115]. The extraction of bioactive compounds depends on a variety of factors, such as the frequency used and usually between $20 \mathrm{kHz}$ and $100 \mathrm{MHz}$ [116], solvent selection, solvent concentration, solid-solvent ratio, temperature, and time extraction (Table 2B).

Among the flavonoid compounds that have been extracted and recovered using this methodology are the following: Rutin, narcissin, nicotiflorin, epicatechin, epicatechin gallate, catechin, procyanidin $\mathrm{B}_{2}$, apiofuranosyl $\left(1^{\prime \prime \prime} \rightarrow 2^{\prime \prime}\right)-\beta$-D-glucopyranosyl] rhamnocitrin, quercetin-3 -O-rhamnoglucoside, quercetin-3-O- $\beta$-D-glucopyranoside, myricetin- $5^{\prime}-O-\beta$-D-glucopyranoside, $4^{\prime}-O-\left(3^{\prime \prime \prime}-O\right.$-dihydrophaseoyl- $\beta$-D-glucopyranosyl) rhamnocitrin, formononetin-7-O-glucoside, myricomplanoside, kaempferol-3-O-glucosylrutinoside, complantoside A, quercetin-3-O-acylglycoside, etc. [117-119].

\subsubsection{Supercritical Fluid Extraction}

Any substance at a temperature and pressure above its thermodynamic critical point is a supercritical fluid. Under these conditions, the properties of the fluids generate a high diffusivity and low viscosity of the solvents used to improve the process of transfer of the matter [120]. Due to this, the SFE methodology (Figure 4) has reported flavonoid extraction yields much higher than those used in other techniques [121].

The most commonly used solvent in this extraction method is carbon dioxide $\left(\mathrm{CO}_{2}\right)$ due to its numerous advantages, such as that it is flammable, nontoxic, cheap, and very easy to remove due to its volatility $[123,124]$. It is a strong solvent for supercritical extraction with all these features.

Certain advantages of this extraction methodology are low temperatures that maintain the integrity of the products, high volatility of the solvents which keep the waste low, the extraction is carried out without phase changes, easy separation of volatile and nonvolatile compounds. However, they present some limitations such as the difficult equilibrium between solute and solvent, may require other separation processes, high pressures hinder the continuous addition of solids to the extract, operating costs are high, equipment is low, maintenance cost is high, etc. [125,126]. 


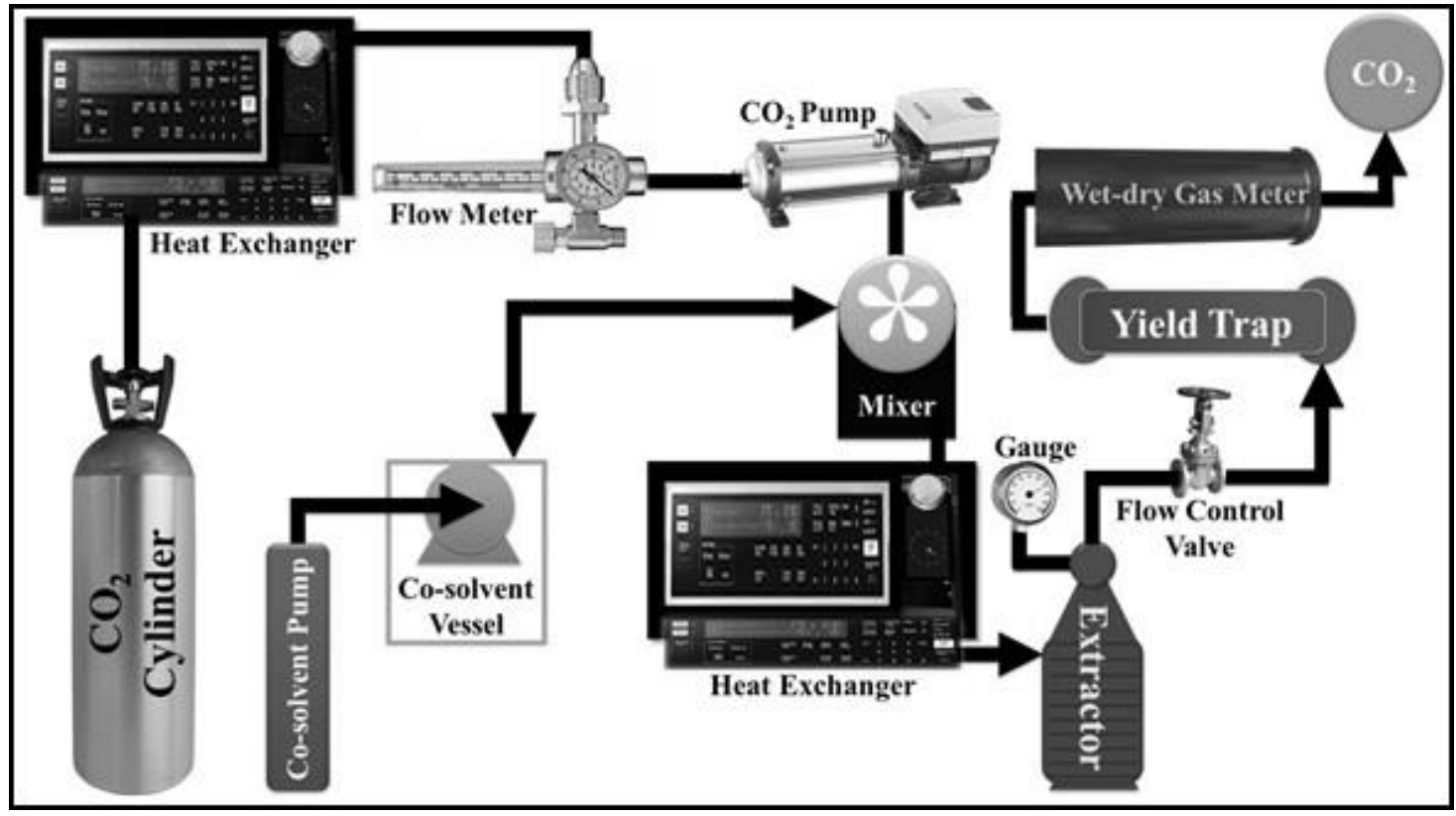

Figure 4. Schematic setup of supercritical fluid extraction (SFE) [122].

Temperature is one of the most important factors in the process. In this methodology, the use of reduced temperatures is intended to keep the product as stable as possible. In one study, for example, the valorization of agro-industrial residues (expellers) from the extraction of soybean oil by pressing was analyzed. Extractions were carried out at $40 \mathrm{MPa}$ and at 35 or $40{ }^{\circ} \mathrm{C}$ using $\mathrm{CO}_{2}$ as a solvent. Moreover, the expellers were impregnated with ethanol. The best results showed the flavonoids content of 65.0 and 31.3 QE/100 gdm [127]. On the other hand, flavonoids were extracted from Odontonema strictum leaves with supercritical carbon dioxide and ethanol. The effect of temperature $\left(55-65{ }^{\circ} \mathrm{C}\right)$ on the total flavonoid content was optimized. The total flavonoid content and flavonoid recovery vary respectively from 99.33 to $247.78 \mathrm{mg} / \mathrm{g}$ of dried extract and 10.68-18.92 mg/g of dried leaves powder [128]. In another study, supercritical $\mathrm{CO}_{2}$ extraction with/without ethanol from Citrus unshiu peels was examined at a temperature of $59.85^{\circ} \mathrm{C}$ and a pressure of $30 \mathrm{MPa}$. The best results obtained were that the extracts, including nobiletin, increased the concentration of ethanol in supercritical $\mathrm{CO}_{2}$ and increased the time of extraction. On the other hand, the role of pressure in these methods is very important and depends on the solvent used. For example, an effective method of extracting Medicago sativa using enzyme-assisted supercritical fluid was developed in another study. The design of the Box-Behnken was chosen to optimize the extraction process parameters, including pressure (100-300 bar). Optimal extraction parameters for total polyphenol content were: $68^{\circ} \mathrm{C}, 205 \mathrm{bar}$, and $15.5 \%$ for temperature, pressure and co-solvent content, respectively. This methodology provides effective enzyme-assisted supercritical fluid extraction for the enhanced release of polyphenol compounds [129]. Supercritical fluids are a more efficient, safer, and environmentally friendly method for extracting and recovering flavonoids for the purpose of bioactive compounds study (Table 2C).

\subsubsection{Enzyme and Microorganism-Assisted Extraction}

There are several different techniques for the extraction of flavonoids, including conventional solid-liquid extraction, pressurized fluid extraction, pressurized hot water extraction. Supercritical fluid extraction, MAE, UAE, and pulsed electrical field extraction are among the most sustainable alternatives to these traditional methods [130]. The process of extraction of flavonoids is usually performed using organic solvents mixed with or without water. The extraction can be controlled by different parameters, such as the selection of extraction procedures, as well as the flow rate used for 
extraction, solvent and temperature, pressure and time. In addition, other techniques have yielded similar results; these techniques involve the use of microorganism-and enzyme-assisted extractions.

Enzyme-assisted extraction is a promising alternative to conventional extraction methods where a high amount of solvent is used. The advantages of this method are regioselectivity and specificity of enzyme action, their ability to catalyze reactions in aqueous solutions under mild conditions [131]. Furthermore, the application of enzyme is an environmentally friendly method for the extraction of flavonoids due to a decrease in solvent quantity in order to reduce extraction times and increase extraction yield and quality of flavonoids. Enzymes and microorganisms may also be used for pretreatment in different agro-industrial and food industries.

Enzymes obtained from fungi, bacteria, vegetable extracts and animal organs, such as pectinases, different glucanases, hemicellulases, cellulases, etc., in mixtures or alone, break down the cell wall by hydrolysis of biopolymeric components to increase the permeability of the cell wall and also increase the yield of flavonoids and other physiologically active extractants [132,133].

Hydrolytic enzymes can break down the cell wall of polysaccharides to improve intracellular release. Cellulose is hydrolyzed by four classes of enzymes: Endo-and exoglucanases, cellobiohydrolases, and $\beta$-glucosidases. The main chain of hemicellulose can be hydrolyzed by endooxylanases, endomannanases, $\beta$-xylosidases, and $\beta$-mannanases. Degradation of the backbone of pectin requires a number of enzymes such as pectin lyases, pectate lyases, endoand exo-polygalacturonases, endo- and exo-rhamnogalacturonases and rhamnogalacturan lyases. In addition, to hydrolyze the side chains of polysaccharides, by-product enzymes (such as arabinases, galactosidases and feruloyl, esterases) are needed [134].

Several authors have utilized enzymatic treatments with commercial preparations for the extraction of flavonoids from plant material (Table 3). These commercial enzymes usually have one or more main hydrolytic activities and a number of side activities. Commercial pectinases have been used for enzyme-assisted extraction of black currant phenols (Ribes nigrum) juice press residues [135]. Mixtures of pectinases and cellulases have been used for the extraction of polyphenols from grape pomace $[136,137]$. A combination of enzymatic hydrolysis and ultrasonic-assisted extraction was used for the extraction of flavonoids from pigeon pea (Cajanus cajan) leaves [138], celery (Apium graveolens) leaves [139], shepherd's purse (Capsella bursa-pastoris) pulp [140], and mulberry (Morus nigra) must [141]. A set of combinations of different extraction methods (viz. enzymatic hydrolysis, ultrasonic, and microwave-assisted extraction) that were used for the recovery of flavonoids from Nitraria tangutorun juice by-product [142].

Special attention must be paid to the presence of undesirable enzyme activities during the enzyme-assisted extraction of flavonoids. These activities may be caused by endogenous enzymes of plant material or by side activities of commercial preparations. Polyphenol oxidases may induce coupled oxidative browning reactions; $\beta$-glucosidases, $\beta$-galactosidases, and $\alpha$-L-arabinosidases may hydrolyze native glycosylated anthocyanins and cause unstable aglycons [135]. For example, Kammerer et al. (2005) [136] observed a low yield of anthocyanin recovery (2.9\%) during enzyme-assisted extraction of polyphenols from grape pomace (Vitis vinifera) at the pilot plant level. This low yield was associated with the action of endogenous enzymes. In subsequent research, thermal inactivation of endogenous enzymes prior to aqueous extraction and enzyme treatment allowed $63.6 \%$ of anthocyanins to be recovered from grape pomace [137].

Landbo and Meyer (2001) [135] found that two commercial pectinases had a negative effect on the recovery of anthocyanins during enzyme-assisted extraction of phenolic compounds from black currant (Ribes nigrum) pomace. This negative effect was associated with the presence of glycosidase activities in enzyme preparations. On the other hand, Xu et al. (2013b) [145] used the activity of glycosylase present in commercial enzyme preparations to improve the extraction of bioactive compounds from two medicinal plants (Glycyrrhizae radix and Scutellariae radix). Bifunctional enzymes were used for the simultaneous degradation of the cell wall and deglycosylation of native flavonoid glycosides. 
Table 3. Studies on enzyme assisted isolation and extraction of flavonoids from different plant sources.

\begin{tabular}{|c|c|c|c|}
\hline Source & Enzyme (s) & Compound (s) & Reference \\
\hline Ginkgo biloba leaves & Cellulase & Flavonols & [143] \\
\hline Grape (Vitis vinifera) skins & $\begin{array}{l}\text { Oenological preparation } \\
\text { (pectinase }+ \text { cellulase }+ \\
\text { hemicellulase) }\end{array}$ & $\begin{array}{l}\text { Anthocyanins, flavonol } \\
\text { glycosides, and flavan-3-ols }\end{array}$ & [144] \\
\hline Mulberry (Morus nigra) must & Pectinase & $\begin{array}{c}\text { Anthocyanins and } \\
\text { nonanthocyanin flavonoids }\end{array}$ & [141] \\
\hline $\begin{array}{l}\text { Nitraria tangutorum juice } \\
\text { by-products }\end{array}$ & Cellulase & $\begin{array}{c}\text { Anthocyanins and } \\
\text { nonanthocyanin flavonoids }\end{array}$ & [142] \\
\hline $\begin{array}{c}\text { Shepherd's purse (Capsella } \\
\text { bursa-pastoris) pulp }\end{array}$ & Pectinase and cellulase & Flavonoids & [140] \\
\hline Glycyrrhizae radix & Cellulase & $\begin{array}{l}\text { Liquiritigenin and } \\
\text { isoliquiritigenin }\end{array}$ & [145] \\
\hline $\begin{array}{c}\text { Celery (Apium graveolens) } \\
\text { leaves }\end{array}$ & Pectinase & Luteolin and apigenin & [139] \\
\hline Scutellariae radix & Naringinase & Bacalein and wogonin & [146] \\
\hline Grape (Vitis vinifera) pomace & Pectinase and cellulase & $\begin{array}{c}\text { Anthocyanins and } \\
\text { nonanthocyanin flavonoids }\end{array}$ & [137] \\
\hline $\begin{array}{c}\text { Pigeonpea (Cajanus cajan) } \\
\text { leaves }\end{array}$ & Pectinase & Luteolin and apigenin & [138] \\
\hline Grape (Vitis vinifera) pomace & Pectinase and cellulase & $\begin{array}{c}\text { Anthocyanins and } \\
\text { nonanthocyanin flavonoids }\end{array}$ & [136] \\
\hline $\begin{array}{l}\text { Black currant (Ribes nigrum) } \\
\text { pomace }\end{array}$ & Pectinase & Anthocyanins & [135] \\
\hline
\end{tabular}

Chen et al. (2011) [146] developed a method for enzyme-assisted extraction of flavonoids from Ginkgo biloba leaves in which the enzyme was used not only for cell wall degradation but also to increase the solubility of target compounds. They used commercial Penicillium decumbens cellulase with high transglycosylation activity. The presence of maltose $P$. decumbens cellulase transglycosylated flavonol aglycones in more polar glucosides with higher solubility in polar solvents improves the extraction yield.

The parameters to be taken into account for increasing the extraction yield of flavonoids are treatment time, $\mathrm{pH}$, and temperature, as well as the enzyme quantity in relation to the concentration of the substrate. Various studies reported the optimization of these parameters [143,144].

There are also disadvantages of enzymatic methods, which have been reported in many reports: To date, the enzyme tested has not been able to achieve complete plant cell wall hydrolysis due to the major difficulties of scale-up enzyme-assisted extraction at industrial level and the relatively high cost of biocatalyst for large volumes of raw materials [132]. The use of microorganisms as enzyme producers may replace the use of food-grade enzymes in the extraction of flavonoids. However, their growth and activity are sensitive to changes in environmental conditions (temperature, percentage of dissolved oxygen, agitation rate, design of reactors, and availability of nutrients) [147].

\section{Transformation of Flavonoids}

\subsection{Microbial Biotransformation}

Biotransformation of flavonoids to increase the biological activity of the recovered compounds is a trend. Biotransformation is a process in which the chemical structure of the compounds is modified by the use of microorganisms. The objective of biotransformation is to produce fine chemical compounds (high added value) that are difficult to produce by chemical synthesis under low-severity 
reaction conditions. These processes have good production yields and the recovery of flavonoids. The main biotransformations reported in flavonoids are as follows: Dehydroxylation, dehydrogenation, hydrogenation, glycosylation, O-methylation, O-demethylation, deglycosylation, cyclization, sulfation, and carbonyl reduction [148]. This section discusses some biotransformation studies on flavonoids using filamentous fungi and bacteria.

Filamentous fungi and 20 strains of Streptomyces for the production of flavonoids were evaluated and two derivatives of quercetin were obtained from Beauveria bassiana ATCC7159 in the bioconversion of quercetin. Furthermore, the bioconversion of rutin was obtained by Cunninghamella echinulata ATCC 9244 rutin sulfate, rutin glucuronide, and rutin methylation. This biotechnology method was appropriate to produce biologically-active flavonoids [149]. In another study, the biodegradation of isoflavones into 4'-fluoroisoflavone were evaluated by Aspergillus niger and Cunninghamella elegans strains and obtained more than 20 metabolites. A. niger was the microbial strain that has the most ability to degrade isoflavones which could be used as bioactive compounds [150]. Furthermore, the biotransformation of icariin, epimedin C, epimedoside A, epimedin A, and epimedin B were evaluated from the Epimedium koreanum plant using Cunninghamella blakesleana. This process generated flavonoids that posed potential applications in the pharmaceutical and food industries [151].

A new method was developed to produce genistein from roots of pigeon pea (Cajanus cajan) using immobilized strains of Aspergillus oryzae and Monacus anka. This biotransformation method was a good alternative to the production of genistein from plants with food industry potential [152]. Different filamentous fungi used in solid-state fermentation were evaluated for the biotransformation of phenolic compounds in cauliflower leaves. A. sojae strain was best suited to high yields of flavonoids, including kaempferol-derived metabolites. This bioprocess was proposed as an alternative for the development of the concept of bio-refinery and the use of agricultural by-products [153]. In another study, a process of biotransformation of phenolic compounds from citrus waste using solid-state fermentation by Peacilomyces variotii was developed, where remarkable production of naringenin and hesperetin was achieved and the antioxidant capacity increased to $73 \%$. These compounds are of high added value that can be used in the food sector [154].

Moreover, a strategy for the biodegradation pathway from tyrosine to the production of fisetin using Escherichia coli has been developed. The production of this flavonoid is of great interest because it has different biological properties for human health, such as antiviral and anticancer [155]. In another study, the biotransformation of soy isoflavones in ortho-hydroxyisoflavones was evaluated using CYP105D7 from Streptomyces avermitilis MA4680 and expressed in Pichia pastoris. This study provides evidence of the great potential of the use of genetic microorganisms for the production of isoflavonoids for food industry applications [156]. Puerarin catalyzed by Bacillus cereus NT02 was evaluated for its biotransformation. The results showed that puerarin phosphorylation innovations in medicinal chemistry have particular importance [157].

\subsection{Enzyme-Catalyzed Transformation}

Flavonoids are characterized by their low solubility and stability in aqueous and lipid phases. For instance, aglycones are less soluble than their derivatives. Aglycones are readily absorbed by passive diffusion through biological membranes, while flavonoid glucosides can be introduced into cells by means of a sodium-dependent glucose transporter 1 . Therefore, deglycosylation is important for the assimilation of dietary flavonoids [158]. They may be modified chemically, enzymatically, or chemo-enzymatically to enhance these properties.

Glycosylation and acylation are the most important transformations of flavonoids catalyzed by enzymes. Glycosylation allowed flavonoids to enhance their hydrophilic character by adding sugars, while acylation makes them more hydrophobic due to the combination of fatty acids. Chemical acylation is not regioselective [159] and results in the modification of phenolic groups responsible for the antioxidant activity of flavonoids [158]. The enzyme groups used for flavonoid transformation are presented in Table 4. 
Table 4. Flavonoids transformation catalyzed by different enzymes.

\begin{tabular}{|c|c|c|c|}
\hline $\begin{array}{l}\text { Enzymes } \\
\text { Type }\end{array}$ & & Transformation & Reference \\
\hline Esterases & $\begin{array}{l}\text { Esterases (carboxyl } \\
\quad \text { esterases) }\end{array}$ & $\begin{array}{l}\text { Reaction similar to lipases, but with short-chain } \\
\text { fatty acids and difference in the interfacial } \\
\text { activation. Low practical applications in } \\
\text { enzymatic transformation of flavonoids with a } \\
\text { short aliphatic chain length such as acetate, } \\
\text { propionate, and butyrate. }\end{array}$ & [160] \\
\hline Isomerase & $\begin{array}{l}\text { Chalcone isomerase } \\
\qquad(\mathrm{CHI})\end{array}$ & $\begin{array}{l}\text { Cyclization of chalcone to form flavanone, } \\
\text { transformation of chalcone and } 6^{\prime} \text {-deoxychalcone } \\
\text { into }(2 S) \text {-naringerin and }(2 S) \text {-5-deoxyflavanone. } \\
\text { Soybean CHIs do not require the } 4^{\prime} \text {-hydroxy } \\
\text { moiety on the substrate for high enzyme activity. }\end{array}$ & [161] \\
\hline Laccase & $\begin{array}{l}\text { Laccase from } \\
\text { Myceliophthora }\end{array}$ & $\begin{array}{l}\text { Synthesis of a flavonoid polymer and high } \\
\text { molecular fraction of extracted flavonoids from } \\
\text { rutin as substrate in the mixture of methanol and } \\
\text { buffer. Oxidation of catechin in the presence of } \\
\text { gelatin and synthesize the gelatin-catechin } \\
\text { conjugate. }\end{array}$ & {$[162,163]$} \\
\hline \multirow[t]{2}{*}{ Lipase } & $\begin{array}{l}\text { Candida antarctica lipase } \\
\text { B }\end{array}$ & $\begin{array}{l}\text { Acetylation only on the primary } 6^{\prime}-\mathrm{OH} \text { of the } \\
\text { isoquercitrin glucose and the secondary } 4^{\prime}-\mathrm{OH} \text { of } \\
\text { the rutin rhamnose were expected to be } \\
\text { acetylated. }\end{array}$ & \multirow[t]{2}{*}{ [164] } \\
\hline & $\begin{array}{l}\text { Pseudomonas cepacea } \\
\text { lipase }\end{array}$ & $\begin{array}{c}\text { Acetylation occurred only on } 3^{\prime}-\mathrm{OH}, 5^{\prime}-\mathrm{OH} \text {, and } \\
\text { 7-OH hydroxyls. }\end{array}$ & \\
\hline \multirow[t]{2}{*}{$\begin{array}{l}\text { Pectinase } \\
\text { and } \\
\text { Cellulase }\end{array}$} & $\begin{array}{l}\text { Commercial Cellulases } \\
\text { from Trichoderma viride }\end{array}$ & $\begin{array}{c}\text { Transglucosylation activity toward (+)-catechin } \\
\text { and (-)-epigallocatechin gallate (EGCG) using } \\
\text { dextrin as a glucosyl donor. EGCG glucosides } \\
\text { were functionally superior to EGCG as food } \\
\text { additives. }\end{array}$ & \multirow[t]{2}{*}[146,165,166]{} \\
\hline & $\begin{array}{l}\text { Pectinolytic and } \\
\text { Cellulolytic Enzymes }\end{array}$ & $\begin{array}{l}\text { Hydrolysis of main- and side-chain of } \\
\text { polysaccharides, and glycosidase activities. }\end{array}$ & \\
\hline \multirow[t]{2}{*}{ Peroxidase } & Chloroperoxidase & $\begin{array}{l}\text { Halogenation of naringenin and hersperetin, at } \\
\text { C- } 6 \text { and C- } 8 \text { with chloride and bromide ions. }\end{array}$ & \multirow[t]{2}{*}[167,168]{} \\
\hline & Horseradish peroxidase & $\begin{array}{l}\text { Conjugation of green-tea catechin with amine } \\
\text { substituted octahedral silsesquioxane. }\end{array}$ & \\
\hline \multirow{4}{*}{ Protease } & $\begin{array}{l}\text { Alkaline protease from } \\
\text { Bacillus subtilis }\end{array}$ & $\begin{array}{l}\text { Synthesis of } 3 " \text {-O-substituted vinyl rutin esters in } \\
\text { pyridine. }\end{array}$ & \multirow{4}{*}{ [169-171] } \\
\hline & Novozym 435 & $\begin{array}{l}\text { Synthesis of } 4 " \text { - O-substituted vinyl rutin esters } \\
\text { in tert-butanol. }\end{array}$ & \\
\hline & Proteases & $\begin{array}{l}\text { Hydrolytic and synthetic functions. Enzymatic } \\
\text { transformations of flavonoids were affected by } \\
\text { the type, origin and concentration of enzymes, } \\
\text { nature of flavonoids, donor and optimal } \\
\text { conditions (temperature, substrates, and solvent). }\end{array}$ & \\
\hline & $\begin{array}{l}\text { Subtilisin (serine } \\
\text { protease) }\end{array}$ & $\begin{array}{l}\text { Flavonoid ester synthesis, the selective rutin } \\
\text { acylation in organic solvents with excellent } \\
\text { selectivity. The structure of the sugar moiety } \\
\text { affected the regioselectivity. }\end{array}$ & \\
\hline
\end{tabular}


Table 4. Cont.

\begin{tabular}{|c|c|c|c|}
\hline $\begin{array}{l}\text { Enzymes } \\
\text { Type }\end{array}$ & & Transformation & Reference \\
\hline \multirow{3}{*}{ Transferase } & $\begin{array}{l}\text { Glycosyltransferases } \\
\text { (GTs) }\end{array}$ & $\begin{array}{l}\text { Glycosylation of on one or more of five hydroxyl } \\
\text { groups of flavonol quercetin, as well as formation } \\
\text { of hesperetin-7-glucoside. Some natural GTs is } \\
\text { characterized by low specificity and other by the } \\
\text { stringent specificity for glycosylation patterns. } \\
\text { Positions, number, and length of the sugar } \\
\text { moieties are significant factors for yield reaction. }\end{array}$ & \multirow{3}{*}{ [95,172-175] } \\
\hline & $\begin{array}{c}\text { Prenyltransferase (from } \\
\text { Morus nigra) }\end{array}$ & $\begin{array}{c}\text { Exclusive prenylation of chalcones }(1,2,3 \text {, } \\
\text { bearing two hydroxyl groups }\left(\mathrm{C}-2^{\prime}, \mathrm{C}-4^{\prime}\right) \text { on ring } \\
\text { A) with a } 2^{\prime}, 4^{\prime} \text { dihydroxy substitution and the } \\
\text { isoflavone genistein. The position of substituents } \\
\text { in ring B appeared to be critical for the } \\
\text { prenylation. }\end{array}$ & \\
\hline & $\begin{array}{l}\text { Prenyltransferase } \\
\text { (NovQ): }\end{array}$ & $\begin{array}{l}\text { Transferring of a dimethylallyl group to the } \\
\text { B-ring of flavonoids. Genistein and naringenin } \\
\text { and yielded two products with a dimethylallyl } \\
\text { group at } \mathrm{C}-3^{\prime} \text { or } \mathrm{O}-4^{\prime} \text {. }\end{array}$ & \\
\hline
\end{tabular}

Lipase (Table 4) catalyzed flavonoids acylation with phenolic acids leads to increased solubility, stability, and antioxidant activity of flavonoids in different media [176]. In addition, the presence of electron-donating or withdrawing substituents in the aromatic ring of flavonoids appears to be essential for their activity in the central nervous system as anxiolytic, anticonvulsant, and sedative and skeletal muscle relaxant drugs.

Chemical modifications are complex and laborious work that requires specific conditions. Therefore, enzyme modification can be a very promising alternative technique in this way. It is a well-known enzymatic halogenation of organic compounds by means of chloroperoxidase (EC 1.11.1.10). Chloroperoxidase from Caldariomyces fumago (Table 4) and whole microbial cells were applied to halogenate the flavones, naringenin, and hesperetin, at C-6 and C-8 in the presence of chloride and bromide ions [168]. Biomodified compounds have shown similar properties compared to derivatives obtained by chemical modification using highly aggressive agents such as molecular halogens and hypohalous acid.

The use of different enzymes (Table 4) has been studied in order to find the most potent biocatalyst for the selective transformation of flavonoids (acylation, deacylation, etc.). Applications of thermostable enzymes have been reported [166]. Enzyme immobilization has been performed to increase enzyme stability, facilitate enzyme reuse, and product insulation [177].

The regioselective synthesis of phloridzin-6'-O-cinnamate has been carried out using Candida antarctic lipase B immobilized with a macroporous acrylic resin $[178,179]$. Different enzymes have been used in immobilized forms to reduce the cost of enzymatic modifications of structural flavonoids due to their advantages such as easy isolation and re-use, increased enzyme stability, and regioselectivity in nonaqueous media [164].

Oxidative and conjugative biocatalyzed transformations of flavonoids may be performed in the presence of different microorganisms (Bacillus sp., Aspergillus sp., Saccharomyces cerevisiae, E. coli) [132]. Biotransformations performed by microorganisms consist of very complex mechanisms, including cyclization reactions, condensation, dehydroxylation, hydroxylation, O-dealkylation, alkylation, dehydrogenation, halogenation, double-bond reduction, carbonyl reduction, glycosylation, sulfation, dimerization, or various types of ring degradation. They were described earlier $[132,180,181]$. 


\section{Human Health and Biological Properties}

There is a strong link between a high intake of flavonoids and low cardiovascular disease, neurodegeneration, and cancer in the population in which a food that includes high levels of these phytochemicals is included in a daily diet $[18,22,182]$. These properties are based on protein interaction (enzyme, factor transcription, and receptor transcription) [22]. The use of herbs with a high content of flavonoids has been used as part of traditional remedies to treat various diseases that improve the immune system, as shown by antioxidants, anti-inflammatory, anti-allergenic, and antithrombotic drugs (Figure 5) $[19,183,184]$. There are some reports indicating the pro-oxidant activity of flavonoids [185]. Flavonoids generally act to protect plants from UV-B radiation and have the potential to reduce oxidative damage, act as photoreceptors, and have the power to attract flower pigment pollinators and protect against pathogen attack $[19,23,186]$.

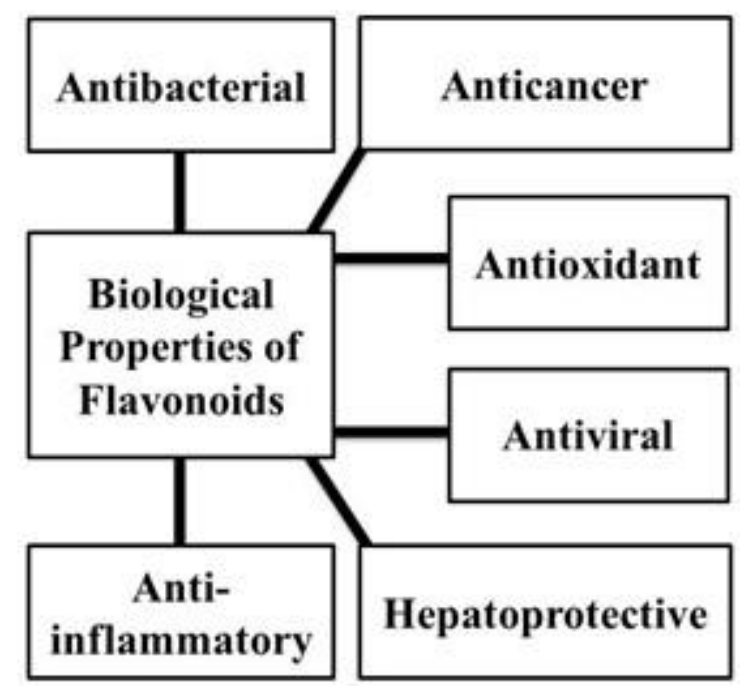

Figure 5. Different biological properties of plant flavonoids for human health and disease.

In particular, isoflavones have shown a variety of effects on human health, especially in women's health, such as the prevention and reduction of climate symptoms (such as hot flushes). The control of diseases such as diabetes, osteoporosis, and breast cancer has also been reported to be associated with the consumption of food rich in isoflavones [28,30,31]. In addition, even for prostate cancer isoflavones have shown their chemical-prevention effect [29].

\section{Concluding Remarks}

Flavonoids are a category of compounds with diverse biological activities that are of interest to various industrial areas, such as food, health pharmaceuticals, and cosmetics. Due to consumers demands today for products that benefit their quality of life substantially. Several extraction methods for the recovery of these flavonoids have been proposed for its wide range of applications. Today, microwave, ultrasound, and supercritical fluid technologies are among the most used methods of flavonoid extraction by most researchers worldwide. In addition, the use of biotechnological alternatives has attracted the attention of research to finding cleaner and more efficient ways to recover flavonoids. These methodologies have been distinguished from conventional methods by a marked increase in extraction yields and the displacement of organic solvents by "green" solvents, as well as a significant decrease in extraction times. Most studies have reported the extraction of flavonoids from vegetable sources such as fruits, seeds, roots or by-products of food, and/or beverage processing such as peels. Although progress has been made in this area, it is necessary to redefine the extractive techniques, since the majority is focused on increasing the yield of total flavonoids, leaving aside the purity of the extracts. The acquisition of extracts and/or purer flavonoid compounds would allow us to 
know more precisely the biological activities and thus to understand the mechanisms of action and the effects on their consumption, allowing for greater diversification of their applications and generating more knowledge in this area.

Author Contributions: Conceptualization, M.L.C.-G. and C.N.A.; literature survey, organization, and critical analysis of data, M.L.C.-G., L.S., H.A.L.-G., L.V.R.-D., A.I., and C.N.A.; initial writing, M.L.C.-G.; revisions and proofreading, M.L.C.-G., D.K.V., L.V.R.-D., and C.N.A.; funding acquisition, M.L.C.-G. and C.N.A. All authors have read and agreed to the published version of the manuscript.

Funding: This research received no external funding.

Conflicts of Interest: The authors declare no conflict of interest.

\section{References}

1. Guo, L.; Gao, L.; Ma, X.; Guo, F.; Ruan, H.; Bao, Y.; Wang, Y. Functional analysis of flavonoid 3'-hydroxylase and flavonoid $3^{\prime}, 5^{\prime}$-hydroxylases from tea plant (Camellia sinensis), involved in the B-ring hydroxylation of flavonoids. Gene 2019, 717, 144046. [CrossRef]

2. Raffa, D.; Maggio, B.; Raimondi, M.V.; Plescia, F.; Daidone, G. Recent discoveries of cancer flavonoids. EJMC 2017, 142, 213-228.

3. Aherne, S.A.; O’Brien, N.M. Dietary flavonols: Chemistry, food content, and metabolism. Nutrition 2002, 18, 75-81. [CrossRef]

4. Amri, F.S.; Hossain, M.A. Comparison of total phenols, flavonoids and antioxidant potential of local and imported ripe bananas. EJBAS 2018, 5, 245-251. [CrossRef]

5. Miao, M.; Cao, L.; Xu, K.; Xin, W.; Zheng, Y. Intervention action of total flavonoids from root of Ilex pubescens in cerebral ischemic tolerance with blood stasis. Saudi J. Biol. Sci. 2017, 24, 729-736. [CrossRef]

6. Moon, K.M.; Lee, B.; Cho, W.K.; Lee, B.S.; Kim, C.K.; Ma, J.Y. Swertiajaponin as an anti-browning and antioxidant flavonoid. Food Chem. 2018, 252, 207-214. [CrossRef]

7. Diwan, V.; Brown, L.; Gobe, G.C. The flavonoid rutin improves kidney and heart structure and function in an adenine-induced rat model of chronic kidney disease. J. Funct. Foods 2017, 33, 85-93. [CrossRef]

8. Geleijnse, J.M.; Launer, L.J.; Van der Kuip, D.A.; Hofman, A.; Witteman, J.C. Inverse association of tea and flavonoid intakes with incident myocardial infarction: The Rotterdam study. AJCN 2002, 75, 880-886. [CrossRef]

9. Spagnuolo, C.; Moccia, S.; Ruso, G.L. Anti-inflammatory effects of flavonoids in neurodegenerative disorders. EJMC 2018, 153, 105-115. [CrossRef]

10. Stahl, W.; Ale-Agha, N.; Polidori, M.C. Non-antioxidant properties of carotenoids. JBC 2002, 383, 553-558. [CrossRef]

11. Xu, M.S.; Chen, S.; Wang, W.Q.; Liu, S.Q. Employing bifunctional enzymes for enhanced extraction of bioactives from plants: Flavonoids as an example. J. Agric. Food Chem. 2013, 61, 7941-7948. [CrossRef]

12. Zuiter, A.S.; Zarqa, J. Proanthocyanidin: Chemistry and biology: From phenolic compounds to proanthocyanidins. In Reference Module in Chemistry, Molecular Sciences and Chemical Engineering; Reedijk, J., Ed.; Elsevier: Amsterdam, The Netherlands, 2014; pp. 1-29.

13. Karabin, M.; Hudcova, T.; Jelinek, L.; Dostalek, P. Biotransformation and biological activities of hop flavonoids. Biotech. Adv. 2015, 33, 1063-1090. [CrossRef]

14. Sharma, V.; Janmeda, P. Extraction, isolation and identification of flavonoid from Euphorbia neriifolia leaves. AJC 2017, 10, 509-514. [CrossRef]

15. Arora, S.; Itankar, P. Extraction, isolation and identification of flavonoid from Chenopodium album aerial parts. JTCM 2018, 8, 476-482. [CrossRef]

16. Martens, S.; Mithöfer, A. Flavones and flavone synthases. Phytochemistry 2005, 66, 2399-2407. [CrossRef]

17. De Villiers, A.; Venter, P.; Pasch, H. Recent advances and trends in the liquid-chromatography-mass spectrometry analysis of flavonoids. J. Chromatogr. A 2016, 1430, 16-78. [CrossRef]

18. Olagaray, K.E.; Bradford, B.J. Plant flavonoids to improve productivity of ruminants-A review. Anim. Feed Sci. Tech. 2019, 251, 21-36. [CrossRef] 
19. Ververidis, F.; Trantas, E.; Douglas, C.; Vollmer, G.; Kretzschmar, G.; Panopoulos, N. Biotechnology of flavonoids and other phenylpropanoid-derived natural products. Part I: Chemical diversity, impacts on plant biology and human health. Biotechnol. J. 2007, 2, 1214-1234. [CrossRef]

20. Kale, A.; Gawande, S.; Kotwal, S. Cancer phytotherapeutics: Role for flavonoids at the cellular level. Phytother. Res. 2008, 22, 567-577. [CrossRef]

21. Cassidy, A.; Kay, C. Phytochemicals: Classification and occurrence. In Encyclopedia of Human Nutrition; Caballero, B., Ed.; Elsevier: Amsterdam, The Netherlands, 2013; pp. 39-46.

22. Rybarczyk-Plonska, A.; Wold, A.B.; Bengtsson, G.B.; Borge, G.I.A.; Hansen, M.K.; Hagen, S.F. Flavonols in broccoli (Brassica oleracea $\mathrm{L}$. var. italica) flower buds as affected by postharvest temperature and radiation treatments. Postharvest Biol. Technol. 2016, 116, 105-114. [CrossRef]

23. Cui, B.; Hu, Z.; Zhang, Y.; Hu, J.; Yin, W.; Feng, Y.; Xie, Q.; Chen, G. Anthocyanins and flavonols are responsible for purple color of Lablab purpureus (L.) sweet pods. Plant Physiol. Biochem. 2016, 103, 183-190. [CrossRef] [PubMed]

24. Xu, Y.; Simon, J.E.; Ferruzzi, M.G.; Ho, L.; Pasinetti, G.M.; Wu, Q. Quantification of anthocyanidins in the grapes and grape juice products with acid assisted hydrolysis using LC/MS. JFF 2012, 4, 710-717. [CrossRef]

25. Oliveira, J.; Mateus, N.; de Freitas, V. Flavanols: Catechins and proanthocyanidins. In Natural Products; Ramawat, K.G., Mérillon, J.M., Eds.; Springer: Berlin/Heidelberg, Germany, 2013; pp. 1753-1801.

26. Pons, Z.; Margalef, M.; Bravo, F.I.; Arola-Arnal, A.; Muguerza, B. Grape seed flavanols decrease blood pressure via Sirt-1 and confer a vasoprotective pattern in rats. JFF 2016, 24, 164-172. [CrossRef]

27. Vuong, Q.V.; Golding, J.B.; Nguyen, M.; Roach, P.D. Extraction and isolation of catechins from tea. JSS 2010, 33, 3415-3428. [CrossRef] [PubMed]

28. Zhao, C.C.; Kim, P.H.; Eun, J.B. Influence of high-intensity ultrasound application on the physicochemical properties, isoflavones composition and antioxidant activity of tofu whey. LWT-Food Sci. Technol. 2020, 117, 108618. [CrossRef]

29. Duru, K.C.; Kovaleva, E.; Danilova, I.; Belousova, A. Production and assessment of novel probiotic fermented oat flour enriched with isoflavones. LWT-Food Sci. Technol. 2019, 117, 108618. [CrossRef]

30. Nemitz, M.C.; Argenta, D.F.; Koester, L.S.; Bassani, V.L.; von Poser, G.L.; Teixeira, H.F. The international scenario of patents concerning isoflavones. Trends Food Sci. Technol. 2016, 49, 85-95. [CrossRef]

31. Ganzera, M. Supercritical fluid chromatography for the separation of isoflavones. J. Pharm. Biomed. Anal. 2015, 107, 364-369. [CrossRef]

32. Alara, O.R.; Abdurahman, N.H.; Ukaegbu, C.I. Soxhlet extraction pf phenolic compounds from Vernonia cinereal leaves and its antioxidant activity. J. Appl. Res. Med. Aromat. Plants 2018, 11, 12-17.

33. Sati, P.; Dhyani, P.; Bhatt, I.D.; Pandey, A. Ginkgo biloba flavonoid glycosides in antimicrobial perspective with reference to extraction method. JTCM 2019, 9, 15-23. [CrossRef]

34. Mackela, I.; Andriekus, T.; Venskutonis, P.R. Biorefinning of buckwheat (Fagopyru, esculentum) hulls by using supercritical fluid, Soxhlet, pressurized liquid and enzyme-assisted extraction methods. JFE 2017, 213, 38-46. [CrossRef]

35. Cujic, N.; Svikin, K.; Jankovic, T.; Pljevljakusic, D.; Zdunic, G.; Ibric, S. Optimization of polyphenols extraction from dried chokeberry using maceration as traditional technique. Food Chem. 2016, 194, 135-142. [CrossRef]

36. Pereira, S.V.; Reis, R.A.S.P.; Garbuio, D.C.; de Freitas, L.A.P. Dynamic maceration of Matricaria chamomilla inflorescences: Optimal conditions for flavonoids and antioxidant activity. Rev. Bras. Farmacogn. 2018, 28, 111-117. [CrossRef]

37. Agustin-Salazar, S.; Medina-Juárez, L.A.; Soto-Valdez, H.; Manzanares-López, F.; Gámez-Meza, N. Influence of the solvent system on the composition of phenolic substances and antioxidant capacity of extracts of grape (Vitis vinifera L.) marc. AJGWR 2014, R20, 208-213. [CrossRef]

38. Albuquerque, B.R.; Prieto, M.A.; Vazquez, J.A.; Barreirio, M.F.; Barros, L.; Ferreira, I.C.F.R. Recovery of bioactive compounds form Arbutus unedo L. fruits: Comparative optimization study of maceration/ microwave/ultrasound extraction techniques. Food Res. Int. 2018, 109, 455-471. [CrossRef]

39. Farzaneth, V.; Carvalho, I.S. Modelling of Microwave Assisted Extraction (MAE) of Anthocyanins (TMA). JARMAP 2017, 6, 92-100.

40. Ye, C.L.; Liu, X.G. Extraction of flavonoids from Tetrastigma hemsleyanum diels et gilg and their antioxidant activity. JFPP 2015, 39, 2197-2205. 
41. Safdar, M.N.; Kausar, T.; Jabbar, S.; Mumtaz, A.; Ahad, K.; Saddozai, A.A. Extraction and quantification of polyphenols from kinnow (Citrus reticulate L.) peel using ultrasound and maceration techniques. JFDA 2017, 25, 488-500. [CrossRef]

42. Bergeron, C.; Gafner, S.; Clausen, E.; Carrier, D.J. Comparison of the Chemical Composition of Extracts from Scutellaria lateriflora Using Accelerated Solvent Extraction and Supercritical Fluid Extraction versus Standard Hot Water or 70\% Ethanol Extraction. J. Agric. Food Chem. 2005, 53, 3076-3080. [CrossRef]

43. Yu, M.; Wang, B.; Qi, Z.; Xin, G.; Li, Q. Response Surface method was used to optimize the ultrasonic assisted extraction of flavonoids from Crinum asiaticum. Saudi J. Biol. Sci. 2019, 26, 2079-2084. [CrossRef]

44. Daud, M.N.H.; Fatanah, D.N.; Abdullah, N.; Ahmad, R. Evaluation of antioxidant potential of Artocarpus heterophyllus L. J33 variety fruit waste from different extraction methods and identification of phenolic constituents by LCMS. Food Chem. 2017, 232, 621-632. [CrossRef] [PubMed]

45. Szewczyk, K.; Olech, M. Optimization of extraction method for LC-MS based determination of phenolic acid profiles in different Impatiens species. Phytochem. Lett. 2017, 20, 322-330. [CrossRef]

46. Wu, X.; Beecher, G.R.; Holden, J.M.; Haytowitz, D.B.; Gebhardt, S.E.; Prior, R.L. Lipophilic and Hydrophilic Antioxidant Capacities of Common Foods in The United States. J. Agric. Food Chem. 2004, 52, 4026-4037. [CrossRef]

47. Rafińska, K.; Pomastowski, P.; Rudnicka, J.; Krakowska, A.; Maruska, A.; Narkute, M.; Buszewski, B. Effect of solvent and extraction technique on composition and biological activity of Lepidium sativum extracts. Food Chem. 2019, 289, 16-25. [CrossRef] [PubMed]

48. Ku, C.S.; Jang, J.P.; Mun, S.P. Exploitation of polyphenol-rich pine barks for potent antioxidant activity. J. Wood Sci. 2007, 53, 524-528. [CrossRef]

49. Bahorun, T.; Luximon-Ramma, A.; Crozier, A.; Aruoma, O.I. Total phenol, flavonoid, proanthocyanidin and vitamin C levels and antioxidant activities of Mauritian vegetables. J. Sci. Food Agric. 2004, 84, 1553-1561. [CrossRef]

50. Chu, Y.-F.; Sun, J.; Wu, X.; Liu, R.H. Antioxidant and Antiproliferative Activities of Common Vegetables. J. Agric. Food Chem. 2002, 50, 6910-6916. [CrossRef]

51. Zhang, D.; Hamauzu, Y. Phenolics, ascorbic acid, carotenoids and antioxidant activity of broccoli and their changes during conventional and microwave cooking. Food Chem. 2004, 88, 503-509. [CrossRef]

52. Anokwuru, C.P.; Anyasor, G.N.; Ajibaye, O.; Fakoya, O.; Okebugwu, P. Effect of extraction solvents on phenolic, flavonoid and antioxidant activities of three nigerian medicinal plants. Nat. Sci. 2011, 9, 53-61.

53. Vieitez, I.; Maceiras, L.; Jachmanián, I.; Alborés, S. Antioxidant and antibacterial activity of different extracts from herbs obtained by maceration or supercritical technology. JSF 2018, 133, 58-64. [CrossRef]

54. Moreira, M.M.; Barroso, M.F.; Boeykens, A.; Withouck, H.; Morais, S.; Delerue-Matos, C. Valorization of apple tree wood residues by polyphenols extraction: Comparison between conventional and microwave-assisted extraction. Ind. Crop. Prod. 2017, 104, 210-220. [CrossRef]

55. Aspé, E.; Fernández, K. The effect of different extraction techniques on extraction yield, total phenolic, and anti-radical capacity of extracts from Pinus radiata Bark. Ind. Crop. Prod. 2011, 34, 838-844. [CrossRef]

56. Lamounier, K.C.; Cunha, L.C.S.; de Morais, S.A.L.; de Aquino, F.J.T.; Chang, R.; do Nascimento, E.A.; de Souza, M.G.M.; Martins, C.H.G.; Cunha, W.R. Chemical analysis and study of phenolics, antioxidant activity, and antibacterial effect of the wood and bark of Maclura tinctoria (L.) D. Don ex Steud. Altern. Med. 2012, 2012, 1-7.

57. Zhu, H.B.; Wang, Y.Z.; Liu, Y.X.; Xia, Y.L.; Tang, T. Analysis of flavonoids in Portulaca oleracea L. by uv-vis spectrophotometry with comparative study on different extraction technologies. Food Anal. Methods 2010, 3, 90-97. [CrossRef]

58. Li, H.; Deng, Z.; Wu, T.; Liu, R.; Loewen, S.; Tsao, R. Microwave-assisted extraction of phenolics with maximal antioxidant activities in tomatoes. Food Chem. 2012, 130, 928-936. [CrossRef]

59. Cardoso-Ugarte, G.A.; Juárez-Becerra, G.P.; Sosa-Morales, M.E.; López-Malo, A. Microwave-assisted Extraction of Essential Oils from Herbs. JMPEE 2013, 47, 63-72. [CrossRef]

60. Casazza, A.A.; Aliakbarian, B.; Mantegna, S.; Cravotto, G.; Perego, P. Extraction of phenolics from Vitis vinifera wastes using non-conventional techniques. J. Food Eng. 2010, 100, 50-55. [CrossRef]

61. Pan, Y.M.; He, C.H.; Wang, H.S.; Ji, X.W.; Wang, K.; Liu, P.Z. Antioxidant activity of microwave-assisted extract of Buddleia officinalis and its major active component. Food Chem. 2010, 121, 497-502. [CrossRef] 
62. Feng, R.Z.; Wang, Q.; Tong, W.Z.; Xiong, J.; Wei, Q.; Zhou, W.H.; Yin, Z.Q.; Yin, X.Y.; Wang, L.Y.; Chen, Y.Q.; et al. Extraction and antioxidant activity of flavonoids of Morus nigra. Int. J. Clin. Exp. Med. 2015, 8, 22328-22336.

63. Alara, O.R.; Abdurahman, N.H.; Olalere, O.A. Optimization of microwave-assisted extraction of flavonoids antioxidants from Vernonia amygdalina leaf using response surface methodology. Food Bioprod. Process. 2018, 107, 36-48. [CrossRef]

64. Bimakr, M.; Rahman, R.A.; Taip, F.S.; Ganjloo, A.; Salleh, L.M.; Selamat, J.; Hamid, A.; Zaidul, I.S.M. Comparison of different extraction methods for the extraction of major bioactive flavonoid compounds from spearmint (Mentha spicata L.) leaves. Food Bioprod. Process. 2011, 89, 67-72. [CrossRef]

65. Hartonen, K.; Parshintsev, J.; Sandberg, K.; Bergelin, E.; Nisula, L.; Riekkola, M.L. Isolation of flavonoids from aspen knotwood by pressurized hot water extraction and comparison with other extraction techniques. Talanta 2007, 74, 32-38. [CrossRef] [PubMed]

66. Jha, P.; Das, A.J.; Deka, S.C. Optimization of ultrasound and microwave assisted extractions of polyphenols from black rice (Oryza sativa cv. Poireton) husk. J. Food Sci. Technol. 2017, 54, 3847-3858. [CrossRef] [PubMed]

67. Rodríguez-Pérez, C.; Gilbert-López, B.; Mendiola, J.A.; Quirantes-Piné, R.; Segura-Carretero, A.; Ibáñez, E. Optimization of microwave-assisted extraction and pressurized liquid extraction of phenolic compounds from Moringa oleifera leaves by multi-response surface methodology. Electrophoresis 2016, 37, 1938-1946. [CrossRef]

68. Zekovic, Z.; Vladic, J.; Vidovic, S.; Adamovic, D.; Pavlic, B. Optimization of microwave-assisted extraction (MAE) of coriander phenolic antioxidants-Response surface methodology approach. J. Sci. Food Agric. 2016, 96, 4613-4622. [CrossRef] [PubMed]

69. Bouras, M.; Chadni, M.; Barba, F.J.; Grimi, N.; Bals, O.; Vorobiev, E. Optimization of microwave-assisted extraction of polyphenols from Quercus bark. Ind. Crop. Prod. 2015, 77, 590-601. [CrossRef]

70. The, S.S.; Niven, B.E.; Bekit, A.E.A.; Carne, A.; Birch, E.J. Microwave and pulsed electric field extraction of polyphenols from defatted canola seeds cake. Int. J. Food Sci. Technol. 2015, 50, 1109-1115.

71. Liazid, A.; Guerrero, R.F.; Cantos, E.; Palma, M.; Barroso, C.G. Microwave assisted extraction of anthocyanins from grape skins. Food Chem. 2011, 124, 1238-1243. [CrossRef]

72. Tan, S.N.; Yong, J.W.H.; Teo, C.C.; Ge, L.; Chan, Y.W.; Hew, C.S. Determination of metabolites in Uncaria sinensis by HPLC and GC-MS after green solvent microwave-assisted extraction. Talanta 2011, 83, 891-898. [CrossRef]

73. Inoue, T.; Tsubaki, S.; Ogawa, K.; Onishi, K.; Azuma, J.I. Isolation of hesperidin from peels of thinned Citrus unshiu fruits by microwave-assisted extraction. Food Chem. 2010, 123, 542-547. [CrossRef]

74. Li, J.; Zu, Y.G.; Fu, Y.J.; Yang, Y.C.; Li, S.M.; Li, Z.N.; Wink, M. Optimization of microwave-assisted extraction of triterpene saponins from defatted residue of yellow horn (Xanthoceras sorbifolia Bunge.) kernel and evaluation of its antioxidant activity. Innov. Food Sci. Emerg. Technol. 2010, 11, 637-643. [CrossRef]

75. Ballard, T.S.; Mallikarjunan, P.; Zhou, K.; O'Keefe, S. Microwave-assisted extraction of phenolic antioxidant compounds from peanut skins. Food Chem. 2010, 120, 1185-1192. [CrossRef]

76. Kong, Y.; Zu, Y.-G.; Fu, Y.-J.; Liu, W.; Chang, F.-R.; Li, J.; Chen, Y.-H.; Zhang, S.; Gu, C.-B. Optimization of microwave-assisted extraction of cajaninstilbene acid and pinostrobin from pigeonpea leaves followed by RP-HPLC-DAD determination. J. Food Compos. Anal. 2010, 23, 382-388. [CrossRef]

77. Yang, Z.; Zhai, W. Optimization of microwave-assisted extraction of anthocyanins from purple corn (Zea mays L.) cob and identification with HPLC-MS. Innov. Food Sci. Emerg. Technol. 2010, 11, 470-476. [CrossRef]

78. Wang, Y.L.; Xi, G.S.; Zheng, Y.C.; Miao, F.S. Microwave-assisted extraction of flavonoids from Chinese herb Radix puerariae (Ge Gen). J. Med. Plants Res. 2010, 4, 304-308.

79. Périno-Issartier, S.; Zille, H.; Abert-Vian, M.; Chemat, F. Solvent free microwave-assisted extraction of antioxidants from sea buckthorn (Hippophae rhamnoides) food by-products. Food Bioprocess. Technol. 2010, 4, 1020-1028. [CrossRef]

80. Tsubaki, S.; Sakamoto, M.; Azuma, J. Microwave-assisted extraction of phenolic compounds from tea residues under autohydrolytic conditions. Food Chem. 2010, 123, 1255-1258. [CrossRef]

81. Victório, C.P.; Lage, C.L.S.; Kuster, R.M. Flavonoid extraction from Alpinia zerumbet (Pers.) Burtt et Smith leaves using different techniques and solvents. Eclet. Quim. 2009, 34, 19-24. 
82. Yang, L.; Jiang, J.-G.; Li, W.-F.; Chen, J.; Wang, D.-Y.; Zhu, L. Optimum extraction Process of polyphenols from the bark of Phyllanthus emblica L. based on the response surface methodology. J. Sep. Sci. 2009, 32, 1437-1444. [CrossRef]

83. Hayat, K.; Hussain, S.; Abbas, S.; Farooq, U.; Ding, B.; Xia, S.; Jia, C.; Zhang, X.; Xia, W. Optimized microwave-assisted extraction of phenolic acids from citrus mandarin peels and evaluation of antioxidant activity in vitro. Sep. Purif. Technol. 2009, 70, 63-70. [CrossRef]

84. Zheng, X.; Wang, X.; Lan, Y.; Shi, J.; Xue, S.J.; Liua, C. Application of response surface methodology to optimize microwave-assisted extraction of silymarin from milk thistle seeds. Sep. Purif. Technol. 2009, 70, 34-40. [CrossRef]

85. Li, W.; Li, T.; Tang, K. Flavonoids from mulberry leaves by microwave-assisted extract and anti-fatigue activity. Afr. J. Agric. Res. 2009, 4, 898-902.

86. Vian, M.A.; Maingonnat, J.F.; Chemat, F. Clean recovery of antioxidant flavonoids from onions: Optimising solvent free microwave extraction method. J. Chroma A 2009, 1216, 7700-7707.

87. Chen, L.; Jin, H.; Ding, L.; Zhang, H.; Li, J.; Qu, C. Dynamic microwave-assisted extraction of flavonoids from Herba epimedii. Sep. Purif. Technol. 2008, 59, 50-57. [CrossRef]

88. Wang, J.X.; Xiao, X.H.; Li, G.K. Study of vacuum microwave-assisted extraction of polyphenolic compounds and pigment from Chinese herbs. J. Chroma A 2008, 1198-1199, 45-53. [CrossRef] [PubMed]

89. Xiao, W.; Han, L.; Shi, B. Microwave-assisted extraction of flavonoids from Radix astragali. Sep. Purif. Technol. 2008, 62, 614-618. [CrossRef]

90. Chen, L.G.; Ding, L.; Yu, A.M.; Yang, R.L.; Wang, X.P.; Li, J.T.; Jin, H.Y.; Zhang, H.Q. Continuous determination of total flavonoids in Platycladus orientalis (L.) Franco by dynamic microwave-assisted extraction coupled with on-line derivatization and ultraviolet-visible detection. Anal. Chim. Acta 2007, 596, 164-170. [CrossRef]

91. Liu, Z.; Ding, L.; Zhang, H.; Hu, X.; Bu, F. Comparison of the different extraction methods of flavonoids in Epimedium koreamum Nakai by HPLC-DAD-ESI-MSn. J. Liq. Chromatogr. Relat. Tech. 2006, 29, 719-731. [CrossRef]

92. Japón-Luján, R.; Luque-Rodríguez, J.M.; Luque de Castro, M.D. Multivariate optimisation of the microwave-assisted extraction of oleuropein and related biophenols from olive leaves. Anal. Bioanal. Chem. 2006, 385, 753-759.

93. Liu, Z.; Yan, G.; Bu, F.; Sun, J.; Hu, X.; Zhang, H. Analysis of chemical composition of Acanthopanax senticosusleaves applying high-pressure microwave-assisted extraction. Chem. Anal. 2005, 50, 851-861.

94. Li, H.; Chen, B.; Zhang, Z.; Yao, S. Focused microwave-assisted solvent extraction and HPLC determination of effective constituents in Eucommia ulmodies Oliv. (E. ulmodies). Talanta 2004, 63, 659-665. [CrossRef]

95. Williams, G.J.; Zhang, C.; Thorson, J.S. Expanding the promiscuity of a natural-product glycosyltransferase by directed evolution. Nat. Chem. Biol. 2007, 3, 657-662. [CrossRef] [PubMed]

96. Ferreira, T.M.S.; dos Santos, J.A.; Modesto, L.A.; Souza, L.S.; dos Santos, M.P.; Bezerra, D.G.; de Paula, J.A.M. An eco-friendly method for extraction and quantification of flavonoids in Dysphania ambrosioides. Braz. J. Pharmacogn. 2019, 29, 266-270. [CrossRef]

97. Um, M.; Han, T.H.; Lee, J.W. Ultrasound-assisted extraction and antioxidant activity of phenolic and flavonoid compounds and ascorbic acid from rugosa rose (Rosa rugosa Thunb.) fruit. Food Sci. Biotech. 2018, 27, 375-382. [CrossRef]

98. Maran, J.P.; Manikandan, S.; Nivetha, C.V.; Dinesh, R. Ultrasound assisted extraction of bioactive compounds from Nephelium lappaceum L. fruit peel using central composite face centered response surface design. Arab. J. Chem. 2017, 10, S1145-S1157. [CrossRef]

99. Ghasemzadeh, A.; Jaafar, H.; Karimi, E.; Rahmat, A. Optimization of ultrasound-assisted extraction of flavonoid compounds and their pharmaceutical activity from curry leaf (Murraya koenigii L.) using response surface methodology. BMC Complement. Altern. Med. 2014, 14, 318. [CrossRef] [PubMed]

100. Wang, C.; Li, Y.; Yao, L.; Wu, G.; Chang, J.; Shu, C.; Chen, M. Optimization of ultrasonic-assisted extraction of flavonoid from Portulaca oleracea L. by response surface methodology and chemical composition analysis. J. Korean Soc. Appl. Biol. Chem. 2014, 57, 647-653. [CrossRef]

101. Memon, A.A.; Memon, N.; Luthria, D.L.; Bhanger, M.I.; Pitafi, A.A. Phenolic Acids Profiling and Antioxidant Potential of Mulberry (Morus laevigata W., Morus nigra L., Morus alba L.) Leaves and Fruits Grown in Pakistan. Pol. J. Food Nutr. Sci. 2010, 60, 25-32. 
102. Babova, O.; Occhipintia, A.; Capuzzo, A.; Maffei, M.E. Extraction of bilberry (Vaccinium myrtillus) antioxidants using supercritical/subcritical $\mathrm{CO}_{2}$ and ethanol as co-solvent. J. Supercrit. Fluids 2016, 107, 358-363. [CrossRef]

103. Wang, L.; Yang, B.; Du, X.; Yi, C. Optimisation of supercritical extraction of flavonoids from Pueraria lobata. Food Chem. 2008, 108, 737-741. [CrossRef]

104. Chen, Y.; Xie, M.-Y.; Gong, X.F. Microwave-assisted extraction used for the isolation of total triterpenoid saponins from Ganoderma atrum. J. Food Eng. 2007, 81, 162-170. [CrossRef]

105. Flórez, N.; Conde, E.; Domínguez, H. Microwave assisted water extraction of plant compounds. J. Chem. Technol. Biotech. 2015, 90, 590-607. [CrossRef]

106. Krishnan, R.Y.; Chandran, M.N.; Vadivel, V.; Rajan, K.S. Insights on the influence of microwave irradiation on the extraction of flavonoids from Terminalia chebula. Sep. Purif. Technol. 2016, 170, 224-233. [CrossRef]

107. Cassol, L.; Rodrigues, E.; Noreña, C.P.Z. Extracting phenolic compounds from Hibiscus sabdariffa L. calyx using microwave assisted extraction. Ind. Crop. Prod. 2019, 133, 168-177. [CrossRef]

108. Akbari, S.; Abdurahman, N.H.; Yunus, R.M.; Fayaz, F. Microwave-assisted extraction of saponin, phenolic and flavonoid compounds from Trigonella foenum-graecum seed based on two level factorial design. J. Appl. Res. Med. Aromat. Plants 2019, 14, 100212. [CrossRef]

109. Ling, Y.Y.M.; Fun, P.S.; Yeop, A.; Yusoff, M.M.; Gimbun, J. Assessment of maceration, ultrasonic and microwave assisted extraction for total phenolic content, total flavonoid content and Kaempferol yield form Cassia alata via Microstructures Analysis. Mater. Today Proc. 2019, 19, 1273-1279. [CrossRef]

110. Tomaz, I.; Maslov, L.; Stupic, D.; Prenier, D.; Asperger, D.; Karoglan Kontić, J. Multi-response optimization of ultrasound-assisted extraction for recovery of flavonoids from red grape skins using response surface methodology. Phytochem. Anal. 2015, 27, 13-22. [CrossRef]

111. Castro-López, C.; Rojas, R.; Sánchez-Alejo, E.J.; Niño-Medina, G.; Martínez-Ávila, G.C.G. Phenolic Compounds Recovery from Grapefruit and By-Products: An Overview of Extraction Methods, Grape and Wine Biotechnology, Antonio Morata and Iris Loira; IntechOpen: London, UK, 2016. [CrossRef]

112. Chludil, H.D.; Corbino, G.B.; Leicach, S.R. Soil Quality Effects on Chenopodium album Flavonoid Content and Antioxidant Potential. J. Agric. Food Chem. 2008, 56, 5050-5056. [CrossRef]

113. Wang, X.H.; Wang, J.P. Effective extraction with deep eutectic solvents and enrichment by microporous adsorption resin of flavonoids from Carthamus tinctorius L. J. Pharm. Biomed. 2019, 176, 112804. [CrossRef]

114. Chen, M.C.A.J.; Zhang, H.; Li, Z.; Zhao, L.; Qiu, H. Effective extraction of flavonoids from Lycium barbarum L. fruits by deep eutectic solvents-based ultrasound-assisted extraction. Talanta 2019, 203, 16-22.

115. Singanusong, R.; Nipornram, S.; Tochampa, W.; Rattanatraiwong, P. Low Power Ultrasound-Assisted Extraction of Phenolic Compounds from Mandarin (Citrus reticulata Blanco cv. Sainampueng) and Lime (Citrus aurantifolia) Peels and the Antioxidant. Food Anal. Methods 2015, 8, 1112-1123. [CrossRef]

116. Piana, F.; Ciulu, M.; Quirantes-Piné, R.; Sanna, G.; Segura-Carretero, A.; Spano, N.; Mariani, A. Simple and rapid procedures for the extraction of bioactive compounds from Guayule leaves). Ind. Crop. Prod. 2018, 116, 162-169. [CrossRef]

117. Nagendra-Prasad, K.; Yang, B.; Zhao, M.; Ruenroengklin, N.; Jiang, Y. Application of ultrasonication or high-pressure extraction of flavonoids from litchi fruit pericarp. J. Food Process. Eng. 2009, 32, 828-843. [CrossRef]

118. Zhang, Q.A.; Fan, X.H.; Li, T.; Zhang, Z.Q.; Liu, Y.K.; Li, X.P. Optimization of ultrasound extraction for flavonoids from semen astragali complanati and its identification by HPLC-DAD-MS/MS. Int. J. Food Sci. Technol. 2013, 48, 1970-1976. [CrossRef]

119. Xie, Z.; Sun, Y.; Lam, S.; Zhao, M.; Liang, Z.; Yu, X.; Yang, D.; Xu, X. Extraction and isolation of flavonoid glycosides from Flos Sophorae Immaturus using ultrasonic-assisted extraction followed by high-speed countercurrent chromatography. J. Sep. Sci. 2014, 37, 957-965. [CrossRef] [PubMed]

120. Dassoff, E.S.; Li, Y.O. Mechanisms and effects of ultrasound-assisted supercritical $\mathrm{CO}_{2}$ extraction. Trends Food Sci. Tech. 2019, 86, 492-501. [CrossRef]

121. Román Páez, M.; Rivera Narváez, C.; Cardona Bermúdez, L.; Muñoz, L.; Gómez, D.; Passaro Carvalho, C.; Quiceno Rico, J. Guía de Extracción por Fluidos Supercríticos: Fundamentos y Aplicaciones; Servicio Nacional de Aprendizaje-SENA: Rionegro, Colombia, 2016. 
122. Verma, D.K.; Dhakane, J.P.; Mahato, D.K.; Billoria, S.; Bhattacharjee, P.; Srivastav, P.P. Supercritical Fluid Extraction (SCFE) for Rice Aroma Chemicals: Recent and Advance Extraction Method. In Science and Technology of Aroma, Flavour and Fragrance in Rice; Verma, D.K., Srivastav, P.P., Eds.; Apple Academic Press: Waretown, NJ, USA, 2018; pp. 179-198.

123. Belbaki, A.; Louaer, W.; Menial, A.H. Supercritical $\mathrm{CO}_{2}$ extraction of oil from Crushed Algerian olives. J. Supercrit. Fluids 2017, 130, 165-171. [CrossRef]

124. Kavoura, D.; Kyriakopoulou, K.; Papaefstahiou, G.; Spanidi, E.; Gardikis, K.; Louli, V.; Aligiannis, N.; Krokida, M.; Magoulas, K. Supercritical $\mathrm{CO}_{2}$ extraction of Salvia fruticosa. J. Supercrit. Fluids 2019, 146, 159-164. [CrossRef]

125. Song, L.; Liu, P.; Yan, Y.; Huang, Y.; Bai, B.; Hou, X.; Zhang, L. Supercritical $\mathrm{CO}_{2}$ fluid extraction of flavonoid compounds from Xinjiang jujube (Ziziphus jujube Mill.) leaves and associated biological activities and flavonoid compositions. Ind. Crop. Prod. 2019, 139, 111508. [CrossRef]

126. Panja, P. Green extraction methods of food polyphenols from vegetable materials. Curr. Opin. Food Sci. 2018, 23, 173-182. [CrossRef]

127. Alvarez, M.; Cabred, S.; Ramírez, C.; Fanovich, M. Valorization of an agroindustrial soybean residue by supercritical flfluid extraction of phytochemical compounds. J. Supercrit. Fluids 2019, 143, 90-96. [CrossRef]

128. Ouédraogo, J.C.; Dicko, C.; Kini, F.; Bonzi-Coulibaly, Y.; Dey, E. Enhanced extraction of flflavonoids from Odontonema strictum leaves with antioxidant activity using supercritical carbon dioxide flfluid combined with ethanol. J. Supercrit. Fluids 2018, 131, 66-71. [CrossRef]

129. Krakowska, A.; Rafinska, K.; Walczak, J.; Buszewski, B. Enzyme-assisted optimized supercritical flfluid extraction to improve Medicago sativa polyphenolics isolation. Ind. Crop. Prod. 2018, 124, 931-940. [CrossRef]

130. Kala, H.K.; Mehta, R.; Sen, K.K.; Tandey, R.; Mandal, V. Critical analysis of research trends and issues in microwave assisted extraction of phenolics: Have we really done enough. Trends Anal. Chem. 2016, 85, 140-152. [CrossRef]

131. Ilina, A.D. The use of enzymes and microorganisms for solving fundamental and applied problems. Herald of the Russian Academy of Sciences. Rep. Bashortostan 2013, 18, 40-43.

132. Zha, J.; Wu, X.; Gong, G.; Koffas, M.A.G. Pathway enzyme engineering for flavonoid production in recombinant microbes. Metab. Eng. Commun. 2019, 9, e00104. [CrossRef]

133. Castro-Vazquez, L.; Alañón, M.E.; Rodríguez-Robledo, V.; Pérez-Coello, M.S.; Hermosín-Gutierrez, I.; Díaz-Maroto, M.C.; Jordán, J.; Galindo, M.F.; Arroyo-Jimenez, M.D.M. Bioactive flavonoids, antioxidant behaviour, and cytoprotective effects of dried grapefruit peels (Citrus paradisi macf.). Oxid. Med. Cell. Longev. 2016. [CrossRef]

134. Lagaert, S.; Belien, T.; Volckaert, G. Plant cell walls: Protecting the barrier form degradation by microbial enzymes. Semin. Cell Dev. Biol. 2009, 20, 1064-1073. [CrossRef]

135. Landbo, A.K.; Meyer, A.S. Enzyme-assisted extraction of antioxidative phenols from black currant juice press residues (Ribes nigrum). J. Agric. Food Chem. 2001, 49, 3169-3177. [CrossRef]

136. Kammerer, D.; Claus, A.; Schieber, A.; Carle, R. A novel process for the recovery of polyphenols from grape (Vitis vinifera L.) pomace. J. Food Sci. 2005, 70, C157-C163. [CrossRef]

137. Maier, T.; Göppert, A.; Kammerer, D.R.; Schieber, A.; Carle, R. Optimization of a process for enzyme-assisted pigment extraction from grape (Vitis vinifera L.) pomace. EFRT 2008, 227, 267-275. [CrossRef]

138. Fu, Y.J.; Liu, W.; Zu, Y.G.; Tong, M.H.; Li, S.M.; Yan, M.M.; Efferth, T.; Luo, H. Enzyme assisted extraction of luteolin and apigenin from pigeonpea [Cajanus cajan (L.) Millsp.] leaves. Food Chem. 2008, 111, 508-512. [CrossRef]

139. Zhang, Q.; Zhou, M.M.; Chen, P.L.; Cao, Y.Y.; Tan, X.L. Optimization of ultrasonic-assisted enzymatic hydrolysis for the extraction of luteolin and apigenin from celery. J. Food Sci. 2011, 76, C680-C685. [CrossRef] [PubMed]

140. Pan, M.; Wang, S.K.; Yuan, X.L.; Xie, R.Y.; Hong, Y.C.; Liu, H.J. Process study on the ultrasonic assisted enzymatic extraction of flavonoids from shepherd's purse. Adv. Mater. Res. 2013, 634, 1281-1286. [CrossRef]

141. Tchabo, W.; Ma, Y.; Engmann, F.N.; Zhang, H. Ultrasound-assisted enzymatic extraction (UAEE) of phytochemical compounds from mulberry (Morus nigra) must and optimization study using response surface methodology. Ind. Crop. Prod. 2015, 63, 214-225. [CrossRef] 
142. Wu, D.; Gao, T.; Yang, H.; Du, Y.; Li, C.; Wei, L.; Zhou, T.; Lu, J.; Bi, H. Simultaneous microwave/ ultrasonic-assisted enzymatic extraction of antioxidant ingredients from Nitraria tangutorun Bobr. juice by-products. Ind. Crop. Prod. 2015, 66, 229-238. [CrossRef]

143. Tomaz, I.; Maslov, L.; Stupić, D.; Preiner, D.; Ašperger, D.; Kontić, J.K. Recovery of flavonoids from grape skins by enzyme-assisted extraction. Sep. Sci. Technol. 2016, 51, 255-268. [CrossRef]

144. Chávez-Santoscoy, R.A.; Lazo-Vélez, M.A.; Serna-Sáldivar, S.O.; Gutiérrez-Uribe, J.A. Delivery of flavonoids and saponins from black bean (Phaseolus vulgaris) seed coats incorporated into whole wheat bread. Int. J. Mol. Sci. 2016, 17, 222. [CrossRef] [PubMed]

145. Xu, S.L.; Zhu, K.Y.; Bi, C.W.; Yan, L.; Men, S.W.; Dong, T.T.; Tsim, K.W. Flavonoids, derived from traditional chinese medicines, show roles in the differentiation of neurons: Possible targets in developing health food products. Birth Defects Res. Part C Embryo Today 2013, 99, 292-299. [CrossRef]

146. Chen, S.; Xing, X.H.; Huang, J.J.; Xu, M.S. Enzyme-assisted extraction of flavonoids from Ginkgo biloba leaves: Improvement effect of flavonol transglycosylation catalyzed by Penicillium decumbens cellulase. Enzym. Microb. Tech. 2011, 48, 100-105. [CrossRef]

147. Huynh, N.T.; Van Camp, J.; Smagghe, G.; Raes, K. Improved release and metabolism of flavonoids by steered fermentation processes: A review. Int. J. Mol. Sci. 2014, 15, 19369-19388. [CrossRef]

148. Cao, H.; Chen, X.; Jassbim, A.R.; Xiao, J. Microbial biotransformation of bioactive flavonoids. Biotech. Adv. 2015, 33, 214-223. [CrossRef] [PubMed]

149. Frauzino-Araújo, K.C.; de, M.B.; Costa, E.M.; Pazini, F.; Valadares, M.C.; de Oliveira, V. Bioconversion of quercetin and rutin and the cytotoxicity activities of the transformed products. Food Chem. Toxicol. 2013, 51, 93-96. [CrossRef] [PubMed]

150. Lee, J.H.; Oh, E.T.; Chun, S.C.; Keum, Y.S. Biotransformation of isoflavones by Aspergillus niger and Cuuninghamella elegans. J. Korean Soc. Appl. Biol. Chem. 2014, 57, 523-527. [CrossRef]

151. Xin, X.; Fan, G.J.; Sun, Z.; Li, Y.; Lan, R.; Chen, L.; Dong, P. Biotransformation of major flavonoid glycosides in herb epimedii by fungus Cunninghamella blakesleana. J. Mol. Catal. B Enzym. 2015, 122, 141-146. [CrossRef]

152. Jin, S.; Wang, W.; Luo, M.; Mu, F.S.; Li, C.Y.; Fu, Y.J.; Zu, Y.G.; Feng, C. Enhanced extraction genistein from pigeon pea [Cajanus cajan (L.) Millsp.] roots with the biotransformation of immobilized edible Aspergillus oryzae and Monacus anka and antioxidant activity evaluation. Process Biochem. 2013, 48, 1285-1292. [CrossRef]

153. Huynh, T.N.; Smagghe, G.; Gonzales, G.B.; Camp, J.V.; Raes, K. Extraction and bioconversion of kaempferol metabolites from cauliflower outer leaves through fungal fermentation. Biochem. Eng. J. 2016, 116, $27-33$. [CrossRef]

154. Madeira, J.V., Jr.; Mayumi-Nakajima, V.; Alves-Macedo, J.; Alves-Macedo, G. Rich bioactive phenolic extract production by microbial transformation of Brazilian Citrus residues. Chem. Eng. Res. Des. 2014, 92, 1802-1810. [CrossRef]

155. Stahlhut, S.G.; Siedler, S.; Malla, S.; Harrison, S.J.; Maury, J.; Neves, A.R.; Forster, J. Assembly of a novel biosynthetic pathway for production of the plant flavonoid fisetin in Escherichia coli. Metab. Eng. 2015, 31, 84-93. [CrossRef]

156. Chiang, C.M.; Ding, H.Y.; Lu, J.Y.; Chang, T.S. Biotransformation of isoflavones daidzein and genistein by recombinant Pichia pastoris expressing membrane-anchoring and reductase fusion chimeric CYP105D7. J. Taiwan Inst. Chem. Eng. 2016, 60, 26-31. [CrossRef]

157. Yu, L.; Gao, F.; Yang, L.; Xu, L.; Wang, Z.; Ye, H. Biotransformation of puerarin into puerarin-6"'-O-phosphate by Bacillus cereus. J. Ind. Microbiol. Biotech. 2012, 39, 299-305. [CrossRef]

158. Sordon, A.; Poplonski, J.; Tronina, T.; Huszcza, E. Regioselective O-glycosylation of flavonoids by fungi Beauveraia bassiana, Absidia coerulea and Absidia glauca. Bioorg. Chem. 2019, 93, 102750. [CrossRef] [PubMed]

159. Bok, S.H.; Jeong, T.S.; Lee, S.K.; Kim, J.R.; Moon, S.S.; Choi, M.S.; Hyun, B.H.; Lee, C.H.; Choi, Y.K. Flavanone Derivatives and Composition for Preventing or Treating Blood Lipid Level-Related Diseases Comprising Same. U.S. Patent 6455577, 24 September 2002.

160. Hidalgo, A.; Bornscheuer, U.T. Directed evolution of lipases and esterases for organic synthesis. In Biocatalysis in the Pharmaceutical and Biotechnology Industries; Patel, R.M., Ed.; CRC Press: Boca Raton, FL, USA; Taylor and Francis: New York, NY, USA, 2006; pp. 159-175.

161. Tian, L.; Dixon, R.A. Engineering isoflavone metabolism with an artificial bifunctional enzyme. Planta 2006, 224, 496-507. [CrossRef] [PubMed] 
162. Kurisawa, M.; Chung, J.E.; Uyama, H.; Kobayashi, S. Enzymatic synthesis and antioxidant properties of poly(rutin). Biomacromolecules 2003, 4, 1394-1399. [CrossRef] [PubMed]

163. Mandalari, G.; Bennett, R.N.; Kirby, A.R.; Lo Curto, R.B.; Bisignano, G.; Waldron, K.W.; Faulds, C.B. Enzymatic hydrolysis of flavonoids and pectic oligosaccharides from bergamot (Citrus bergamia Risso) peel. J. Agric. Food Chem. 2006, 54, 8307-8313. [CrossRef] [PubMed]

164. Jiao, J.; Gai, Q.Y.; Wang, W.; Zang, Y.P.; Niu, L.L.; Fu, Y.J.; Wang, X. Remarjable enhancement of flavonoid production in a co-cultivation system of Isatis tinctorial L. hairy root cultures and immobilized Aspergillus niger. Ind. Crop. Prod. 2018, 112, 252-261. [CrossRef]

165. Ralston, L.; Subramanian, S.; Matsuno, M.; Yu, O. Partial reconstruction of flavonoid and isoflavonoid biosynthesis in yeast using soybean type I and type II chalcone isomerases. Plant Physiol. 2005, 137, 1375-1388. [CrossRef]

166. Lindahl, S.; Ekman, A.; Khan, S.; Wennerberg, C.; Börjesson, P.; Sjöberg, P.J.; Karlsson, E.N.; Turner, C. Exploring the possibility of using a thermostable mutant of b-glucosidase for rapid hydrolysis of quercetin glucosides in hot water. Green Chem. 2010, 12, 159-168. [CrossRef]

167. Ihara, N.; Kurisawa, M.; Chung, J.E.; Uyama, H.; Kobayashi, S. Enzymatic synthesis of a catechin conjugate of polyhedral oligomeric silsesquioxane and evaluation of its antioxidant activity. Appl. Microbiol. Biotech. 2005, 66, 430-433. [CrossRef]

168. Yaipakdee, P.; Robertson, L.W. Enzymatic halogenation of flavanones and flavones. Phytochemistry 2001, 57, 341-347. [CrossRef]

169. Danieli, B.; Luisetti, M.; Riva, S.; Bertinotti, A.; Ragg, E.; Scaglioni, L.; Bombardelli, E. Regioselective enzyme-mediated acylation of polyhydroxy natural compounds. A remarkable, highly efficient preparation of 6'-acetyl and 6'-O-carboxyacetyl ginsenoside Rg1. J. Org. Chem. 1995, 60, 3637-3642. [CrossRef]

170. Chung, J.E.; Kurisawa, M.; Uyama, H.; Kobayashi, S. Enzymatic synthesis and antioxidant property of gelatin-catechin conjugates. Biotechnol. Lett. 2003, 25, 1993-1997. [CrossRef] [PubMed]

171. Xiao, Y.M.; Wu, Q.; Wu, W.B.; Zhang, Q.Y.; Lin, X.F. Controllable regioselective acylation of rutin catalyzed by enzymes in non-aqueous solvents. Biotechnol. Lett. 2005, 27, 1591-1595. [CrossRef] [PubMed]

172. Vitali, A.; Giardina, B.; Delle Monache, G.; Rocca, F.; Silvestrini, A.; Tafi, A.; Botta, B. Chalcone dimethylallyltransferase from Morus nigra cell cultures. Substrate specificity studies. FEBS Lett. 2004, 557, 33-38. [CrossRef]

173. Moon, Y.H.; Lee, J.H.; Ahn, J.S.; Nam, S.H.; Oh, D.K.; Park, D.H.; Chung, H.J.; Kang, S.; Day, D.F.; Kim, D. Synthesis, structure analyses, and characterization of novel epigallocatechin gallate (EGCG) glycosides using the glucansucrase from Leuconostoc mesenteroides B-1299CB. J. Agric. Food Chem. 2006, 54, 1230-1237. [CrossRef] [PubMed]

174. Nielsen, I.L.F.; Chee, W.S.S.; Poulsen, L.; Offord-Cavin, E.; Rasmussen, S.E.; Frederiksen, H.; Enslen, M.; Barron, D.; Horcajada, M.N.; Williamson, G. Bioavailability is improved by enzymatic modification of the citrus flavonoid hesperidin in humans: A randomized, double-blind, crossover trial. J. Nutr. 2006, 136, 404-408. [CrossRef] [PubMed]

175. Ozaki, T.; Mishima, S.; Nishiyama, M.; Kuzuyama, T. NovQ is a prenyltransferase capable of catalyzing the addition of a dimethylallyl group to both phenylpropanoids and flavonoids. J. Antibiot. 2009, 62, 385-392. [CrossRef]

176. Kobayashi, R.; Itou, T.; Hanaya, K.; Shoji, M.; Hada, N.; Sugai, T. Chemo-enzymatic transformation of naturally abundant naringin to luteolin, a flavonoid with various biological effects. J. Mol. Catal. B Enzym. 2013, 92, 14-18. [CrossRef]

177. Adamczak, M.; Krishna, S.H. Strategies for improving enzymes for efficient biocatalysis. Food Technol. Biotechnol. 2004, 42, 251-264.

178. Enaud, E.; Humeau, C.; Piffaut, B.; Girardin, M. Enzymatic synthesis of new aromatic esters of phloridzin. J. Mol. Catal. B Enzym. 2004, 27, 1-6. [CrossRef]

179. Chebil, L.; Humeau, C.; Falcimaigne, A.; Engasser, J.M.; Ghoul, M. Enzymatic acylation of flavonoids. Process Biochem. 2006, 41, 2237-2251. [CrossRef]

180. Das, S.; Rosazza, J.P.N. Microbial and enzymatic transformations of flavonoids. J. Nat. Prod. 2006, 69, 499-508. [CrossRef] [PubMed]

181. Viskupicova, J.; Ondrejovic, M.; Maliar, T. Enzyme-mediated preparation of flavonoid esters and their applications. Biochemistry 2012, 10, 263-286. 
182. Peterson, J.J.; Dwyer, J.T.; Jacques, P.F.; McCullough, M.L. Associations between flavonoids and cardiovascular disease incidence or mortality in European and US populations. Nutr. Rev. 2012, 70, 491-508. [CrossRef] [PubMed]

183. Koirala, N.; Thuan, N.H.; Ghimire, G.P.; Thang, D.V.; Sohng, J.K. Methylation of flavonoids: Chemical structures, bioactivities, progress and perspectives for biotechnological production. Enzym. Microb. Technol. 2016, 86, 103-116. [CrossRef] [PubMed]

184. Chen, G.L.; Fan, M.X.; Wu, J.L.; Li, N.; Guo, M.Q. Antioxidant and anti-inflammatory properties of flavonoids from lotus plumule. Food Chem. 2019, 277, 706-712. [CrossRef] [PubMed]

185. Treml, J.; Smejkal, K. Flavonoids as potent scavengers of hydroxyl radicals. Compr. Rev. Food Sci. Food Saf. 2016, 15, 720-738. [CrossRef]

186. Agati, G.; Tattini, M. Multiple functional roles of flavonoids in photoprotection. New Phytol. 2010, 186, 786-793. [CrossRef]

(C) 2020 by the authors. Licensee MDPI, Basel, Switzerland. This article is an open access article distributed under the terms and conditions of the Creative Commons Attribution (CC BY) license (http://creativecommons.org/licenses/by/4.0/). 